\title{
Reliability of ion accumulation and growth components for selecting salt tolerant lines in large populations of rice
}

\author{
Tanveer Ul Haq ${ }^{A D F}$, Javaid Akhtar ${ }^{B}$, Katherine A. Steele ${ }^{C}$, Rana Munns ${ }^{D, E}$ and John Gorham ${ }^{C}$

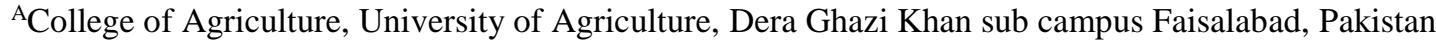 \\ ${ }^{\mathrm{B}}$ Institute of Soil and Environmental Sciences, University of Agriculture, Faisalabad, Pakistan \\ ${ }^{\mathrm{C}}$ College of Natural Sciences, Bangor University, Deiniol Road, Bangor, Gwynedd, Wales LL57 2UW, UK

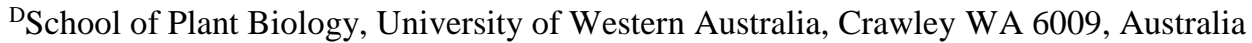 \\ ${ }^{E}$ CSIRO Plant Industry, GPO Box 1600, Canberra ACT 2601, Australia \\ FCorresponding author: Email: dr.tanveer.haq@uaf.edu.pk
}

\section{Abstract}

Ion accumulation and growth under salt stress were studied in two experiments in a rice mapping population derived from parents CO39 and Moroberekan with 4-fold differences in shoot $\mathrm{Na}^{+}$ accumulation. The 120 recombinant inbred lines (RILs) had up to 100 -fold differences in $\mathrm{Na}^{+}$. Measurement of "salt tolerance" (growth of the RILs in $100 \mathrm{mM} \mathrm{NaCl}$ relative to controls after 42 days showed a 2-fold difference in "salt tolerance" between parents, with five RILs being more tolerant than the more tolerant parent CO39. The reliability of various traits for selecting salt tolerance in large populations was explored by measuring $\mathrm{Na}^{+}, \mathrm{K}^{+}$and $\mathrm{K}^{+} / \mathrm{Na}^{+}$ratios in leaf blades and sheaths after 7 or 21 days of exposure to $100 \mathrm{mM} \mathrm{NaCl}$, and their correlation with various growth components and with leaf injury. The highest correlations were found for $\mathrm{Na}^{+}$in the leaf blade on day 21 with injury at day 42 in both experiments (r=0.7). Earlier measurements of $\mathrm{Na}^{+}$or of injury had lower correlations. The most sensitive growth components were tiller number per plant and shoot water content (water per g dry weight), and correlated significantly with $\mathrm{Na}^{+}$and to a lesser extent with $\mathrm{K}^{+} / \mathrm{Na}^{+}$. These studies showed that exposure for at least 42 days may be needed to clearly demonstrate the beneficial effect of the trait for $\mathrm{Na}^{+}$exclusion on growth under salinity.

Additional Keywords: salinity, screening, criteria, HKT transporter, tissue tolerance, sodium, potassium, Oryza sativa 


\section{Introduction}

2 About 950 Mha of the world crop production area has become unsuitable for production due to the problem of soil salinity and/or sodicity (Szabolcs 1989). Rice is one of the most sensitive crops to salt stress (Lafitte et al. 2004) but, its cultivation is recommended during the process of soil reclamation due to its high water requirement which helps leach salts into deeper zones (Bhumbla and Abrol 1978). The world's food security demands that rice production must increase from 600 to 800 million tonnes by the year 2025 (Green et al. 2005). Salt tolerance is a complex trait and understanding its molecular basis is essential for breeding and transformation in crop plants (Yeo and Flowers 1986; Chinnusamy et al. 2005). The promising field of markerassisted breeding can be a powerful tool to increase efficiency of selection for stress adaptation in breeding programs (Witcombe et al. 2008). In rice, many efforts have been made in the past to understand the genetics and physiology of salt tolerance but unfortunately progress is slow due to the complex nature of this multigenic character. It could be partially because of low selection efficiency for general agronomic traits and a lack of effective evaluation methods for assessing salt tolerance among genotypes (Zeng et al. 2003).

The main adverse effects of salinity on plant growth are due to osmotic effects, ionic toxicity and nutritional imbalances such as reduced $\mathrm{K}^{+}$uptake (Läuchli and Epstein 1990). High concentrations of salt around roots affect water relations of the plant and may generate signals which reduce cell expansion rates and stomatal conductance in shoot tissues (Davies and Zhang 1991; Munns 2002). If roots do not exclude most of the salt from the soil solution while taking up water, $\mathrm{Na}^{+}$travelling in the xylem stream may accumulate in leaves to toxic levels causing premature plant death (Munns 2005). Chloride $\left(\mathrm{Cl}^{-}\right)$may accompany the $\mathrm{Na}^{+}$although it is less likely to become toxic (Munns and Tester 2008). Potassium transport is usually decreased and internal osmotic adjustment to grow under saline conditions (Flowers et al. 1977), but glycophytes mainly survive saline environments by excluding most $\mathrm{Na}^{+}$from the transpiration stream (reviewed by Munns 2005). The success of this mechanism in glycophytes depends on the balance between salt influx into the plant and its cellular compartmentation. Too little accumulation of ions in leaves can lead to poor osmotic adjustment, while too much may result in toxic concentrations of $\mathrm{Na}^{+}$and/or $\mathrm{Cl}^{-}$in leaves or reproductive tissues (Flowers et al. 1986). 
1 Exclusion of $\mathrm{Na}^{+}$from photosynthetically active leaves is a key strategy in plants to thrive under 2 salinity (Munns and Tester 2008; Yeo and Flowers, 1986), and the concentration of $\mathrm{Na}^{+}$in leaves of crop plants has been used as one of the indicators of salinity tolerance (Ashraf and Harris 2004; Munns et al. 2006). $\mathrm{Na}^{+}$exclusion was proposed as a criterion for assessing salt tolerance 5 in wheat and rice (Munns et al. 2006; Yeo et al. 1990). Generally, salt tolerant lines of rice maintain lower $\mathrm{Na}^{+}$in their leaves than salt sensitive lines when exposed to salt stress (Flowers and Yeo 1981; Yeo et al. 1990; Lutts and Guerrir 1995). The decrease in $\mathrm{K}^{+} / \mathrm{Na}^{+}$ratio may relate 8 directly to a decrease in yield in some conditions (Asch et al. 2000). More recently, Platten et al. (2013) reported a strong correlation between leaf blade $\mathrm{Na}^{+}$concentration and salt tolerance (as assessed by leaf injury symptoms) in the majority of accessions of two rice species.

Maintenance of a low net uptake of $\mathrm{Na}^{+}$from the soil is accomplished by membranes that have low permeability to $\mathrm{Na}^{+}$. In rice and other cereals, $\mathrm{Na}^{+}$can enter through $\mathrm{K}^{+}$-selective cation transporters such as the 'class 2' HKT transporters (high affinity potassium transporters) that while having a high $\mathrm{K} / \mathrm{Na}$ selectivity would allow uptake of $\mathrm{Na}^{+}$under conditions of high soil $\mathrm{NaCl}$ (Garciadeblas et al. 2003; Horie et al. 2012). $\mathrm{Na}^{+}$may be effluxed from the cells and hence to the soil by the SOS1 $\mathrm{Na}^{+} / \mathrm{H}$ antiporter (Shi et al. 2003) which has an ortholog in rice (Martınez-Atienza 2007). The small fraction that enters the transpiration stream can be further controlled by the 'class 1' HKT transporters which in wheat are suggested to reduce $\mathrm{Na}^{+}$ transport to leaves by the retrieval from transpiration stream and deposition in xylem parenchyma cells (James et al. 2006). In wheat, the transporter encoded by the candidate gene for Nax1, TmHKT1;4, is responsible for retrieval of $\mathrm{Na}^{+}$from the transpiration stream for storage in the leaf sheath tissue (Huang et al. 2006; James et al. 2006). The transporter encoded by the candidate gene for Nax2, TmHKT1;5, plays a similar role, but functions primarily in root tissue (Byrt et al. 2007; Munns et al. 2012). Targeted overexpression of the Arabidopsis HKT1;5 homolog, AtHKT1;1, in Arabidopsis and rice has been shown to increase $\mathrm{Na}^{+}$exclusion from the shoot (Moller et al. 2009; Plett et al. 2010). Cotsaftis et al. (2012) also suggested that retrieval of $\mathrm{Na}^{+}$from the xylem transpiration stream in the root or leaf sheath is a possible mechanism to maintain low $\mathrm{Na}^{+}$in leaf blades of rice, and analysed $\mathrm{Na}^{+}$exclusion in rice by 3D modeling of HKT transporters (OsHKT1;5 and OsHKT1;4). They suggested that $\mathrm{Na}^{+}$accumulation in the leaf blade is controlled by regulation of complex gene expression, alternate splicing and protein structure of transporters under salt stress. 
In a previous study, a recombinant inbred line (RIL) population from the cross between two

2 parents $\mathrm{CO} 39$ and Moroberekan with differences in leaf $\mathrm{Na}^{+}$concentration was chosen to look

3 for QTLs for ion regulation, in the understanding that this would be useful in selecting for salt

4 tolerance. $\mathrm{CO} 39$ has a 4-fold lower $\mathrm{Na}^{+}$concentration in leaves than Moroberekan (Akhtar 2002;

5 Haq et al. 2010). On day 7 of salt stress, two QTLs each for $\mathrm{Na}^{+}$and $\mathrm{K}^{+} / \mathrm{Na}^{+}$ratio in fully

6 expanded leaf were identified on Chromosome 1 with high likelihood of odd (LOD) and

7 explained up to 35 and $38 \%$ of the total phenotypic variation in these traits, respectively (Haq et

8 al. 2010). After 21 days stress same QTL for leaf $\mathrm{Na}^{+}$was detected on Chromosome 1 (11.56 -

$9 \quad 11.72 \mathrm{Mbp}$ ) with LOD of 9.8 and explaining 24\% of the total phenotypic variation. QTLs were

10 also found for $\mathrm{Na}^{+}$accumulation in sheath after 21 days but not after 7 days salt stress (Haq et al

11 2010). Fine mapping identified a chromosomal region that was most likely the same as the SKC1

12 QTL (Lin et al. 2004), later identified as the $\mathrm{Na}^{+}$transporter $O s H K T 1 ; 5$, responsible for retrieval

13 of $\mathrm{Na}^{+}$in rice by being unloaded directly from the xylem sap (Ren et al. 2005).

14 In this paper, which presents results of two experiments with the same parents and population, 15 the relation between leaf $\mathrm{Na}^{+}$and degree of injury over time, and \% biomass production was measured. As the biomass production of the two parents differed substantially in the absence of salt, the first experiment included a control treatment where the effects of salinity on tiller number and total biomass could be calculated, but only small population number could be handled. The second experiment included a larger population number (120 RILs) but with salt treatment only. Here, salt injury over time was measured (day 21 and 42) as well as $\mathrm{Na}^{+}$in sheath and blade of leaf at earlier times to investigate the reliability of leaf injury in predicting future growth in saline conditions and in selection for salt tolerance. This allowed us to relate $\mathrm{Na}^{+}$accumulation to injury, to speculate at what concentration sodium becomes toxic in rice, and to relate this to growth in saline conditions.

\section{Materials and Methods}

\section{Plant material}

The $\mathrm{F}_{9}$ recombinant inbred line (RIL) mapping population employed in this study was developed at the International Rice Research Institute (IRRI), Philippines, from the cross 
CO39 $\times$ Moroberekan. The maternal parent variety CO39 is a salt tolerant lowland Indica cultivar

2 with medium height having originated from India. Moroberekan is a salt sensitive, tropical upland Japonica variety of long stature having its origin in West Africa. The population is skewed towards the CO39 alleles (80\%) (Champoux et al. 1995). In Study-1, a total of 32 RILs

5 were included, whereas in Study-2, a larger set of 120 RILs was investigated for ion accumulation and growth attributes under salt stress.

\section{Sowing of rice nursery}

The rice seeds of RILs and parent varieties (CO39 and Moroberekan) were sown in P-84 plug trays (Desch Plantpak, Malden, UK) filled with John Innes Compost No. 1 (Corwen, Clwyd, UK) at Pen y Ffridd, Research Station, Bangor University, Wales, UK. These trays were kept on a bench in greenhouse (at $25^{\circ} \mathrm{C}$ ) and watered every day until transplantation. Twenty three days after seed sowing, healthy and uniform seedlings of each line (at the three leaf stage) were transplanted into 2 litre plastic pots (one seedling/pot in Study-1 and 2 seedlings/pot in Study-2) lined with horticultural fleece and filled with John Innes No. 2 Compost (Lawrence and Newell 1939).

\section{Setup of flood bench system}

17 Flood bench system was comprised of plastic tanks $(80 \mathrm{~cm} \times 56.3 \mathrm{~cm} \times 32.5 \mathrm{~cm})$ each containing 24 pots of two liters capacity. The water reservoirs each had a capacity of more than 200 litres of water provided with submersible electric pumps. Tanks with plant pots were placed on an iron bench, approximately one meter high from the greenhouse floor. Water reservoirs were placed on the floor underneath the tanks. Submersible electric pumps were placed in water reservoirs to pump water into tanks. There were two connections of the water to each tank, one for water to enter into the tank from the reservoir and the other for water to drain from the tank to the reservoir. Pots were placed into each flood bench tank in a randomized layout with three replications in Study-1 and two replicates in Study-2. The plants were flooded once a day for at least fifteen minutes, twice on hot days and also twice when plants were fully grown in size. Nutrient solution having Phostrogen plant food (Phostrogen, Corwen, Wales, U.K) @ $1.0 \mathrm{~g} \mathrm{~L}^{-1}$ plus $0.5 \mathrm{ml} \mathrm{L}^{-1}$ micro-nutrients (Hoagland and Arnon 1950) and $0.1 \mathrm{ml} \mathrm{L}^{-1}$ sodium silicate were supplied to the plants with the irrigation solution. After establishment of seedlings (one week after transplantation, 28 days after sowing), salt stress was started in daily increments of $25 \mathrm{mM}$ 
and $1.25 \mathrm{mM}$ for $\mathrm{NaCl}$ and $\mathrm{CaCl}_{2}$ respectively to reach the final level of $100 \mathrm{mM} \mathrm{NaCl}+5.0 \mathrm{mM}$

$2 \mathrm{CaCl}_{2}$ except for the controls. Salinity level was maintained in the solution; this was by recording the electrical conductivity (EC) with a portable waterproof conductivity meter (Hanna Instruments, U.K) in each reservoir twice a week. Water lost by transpiration and evaporation

5 was replaced to keep the reservoir volume at 200 litres. Supplementary 400 Watt high pressure sodium vapour lamps were used to maintain a minimum photon flux density of photosynthetically active radiation $(400-700 \mathrm{~nm})$ of $350 \mu \mathrm{mol} \mathrm{m} \mathrm{m}^{-2} \mathrm{~s}^{-1}$ during the 16 hour

photoperiod. The minimum temperature was maintained at $25^{\circ} \mathrm{C}$ during the photoperiod and $920^{\circ} \mathrm{C}$ during the dark period.

Parent varieties CO39, Moroberekan and $32 \mathrm{~F}_{9}$ RILs were evaluated for salt tolerance under above growth control and salt conditions for Study-1, and 120 F9 RILS in the salt conditions only for Study-2.

\section{Measurements}

14 In Study-1, after three weeks (day 21) of salt stress, the youngest fully expanded leaf was sampled from each plant for ionic analysis. The samples were washed with distilled water, dried with tissue paper and stored in labeled, $1.5 \mathrm{ml}$ micro centrifuge tubes (Sigma Chemicals, UK)

17 and stored at $-20^{\circ} \mathrm{C}$ in a commercial freezer for two weeks before sap extraction. After thawing, the tissues were crushed with a tapered end steel rod. Two pin holes were made in the base and cap of each eppendorf tube. Each tube was placed inside a second eppendorf tube and centrifuged at $8000 \mathrm{~g}$ for $10 \mathrm{~min}$. The sap was collected into the lower tube and remaining tissue

21 left in the upper one was discarded (Gorham et al. 1997). The sap was either analyzed

22 immediately or frozen for later analysis. Sodium and potassium ions were analyzed in diluted sap 23 with a Jenway PFP-7 flame photometer (Bibby Scientific Limited, Stone, UK). The whole shoot 24 of plants from both control and salt treatments were harvested on day 42 of stress, and tillers per 25 plant, shoot fresh weight, and dry weight was recorded. NEED TO SAY AT WHAT TEMPERATURE AND FOR HOW LONG THEY WERE DRIED.

27 In Study-2, after 7 days of salt stress, one of each pair of seedlings from two replicates were 28 harvested and two tissue samples were taken. These were (i) a fully expanded leaf and (ii) the combined leaf sheaths. Twenty-one days after reaching full salt stress, one tiller of the second 
plant was harvested and samples were taken again from the fully expanded leaf and combined

2 leaf sheath. The samples were washed briefly with distilled water, dried with tissue paper and stored in $1.5-\mathrm{cm}^{3}$ micro centrifuge tubes at $-20^{\circ} \mathrm{C}$ in the freezer for 1 week. Leaf sap was extracted from each sample and ions were determined as described earlier. A portable SPAD-502 Meter (Minolta, Japan) was used to record the chlorophyll in leaves. Each mean value is the average of nine SPAD observations from leaf 1, 2 and 3 (one leaf on each of three tillers) on main tillers of the same plant. The SPAD readings from each leaf were taken from the base, middle and tip, along the length of leaf to cover the whole (or the total) leaf area.

\section{Leaf injury scoring}

In both studies, leaf injury scoring in the saline treatment was done on days 21 (Score-1) and 42 (Score-2) on the top mature leaves on a scale of 1 to 4 . The injury value 1 was assigned to leaves showing little damage, a value of 2 with leaves showing slight damage, a value of 3 where the leaf damage was moderate, and a value of 4 to leaves experiencing severe damage.

Results

In Study-1, the two parents and 32 RILs were grown in control and $100 \mathrm{mM} \mathrm{NaCl}$ for 42 days. The adverse effects of salinity on overall plant appearance and growth after 42 days at $100 \mathrm{mM}$ $\mathrm{NaCl}$ were greater on Moroberekan than on CO39. Moroberekan had more vigorous vegetative growth than $\mathrm{CO} 39$, producing over double the biomass in the absence of salinity (Table 1), so the genetic differences in "salt tolerance" need to be expressed as a \% of growth in the control conditions. Moroberekan produced a shoot fresh weight under salt stress that was only $23 \%$ of the controls, whereas CO39 had a fresh weight that was $42 \%$ of controls (Table 1). Six RILs had an even higher \% shoot fresh weight than CO39 (Fig. 1a). Shoot dry weights showed a similar result (Suppl. Fig. 1a). The variation in shoot fresh and dry weight was highly significant $(\mathrm{p}<0.01)$ in treatments (saline and non-saline), RILs and Salinity $\times$ RIL interactions as is revealed 
by the analysis of variance in Study-1 (Suppl. Table 1). Tillers were the same number (about 12)

2 in both parent varieties in the control treatment, and so could be used to assess effects of salinity on growth in the absence of a control treatment. Under salt stress, the number of tillers plant ${ }^{-1}$ was more in CO39 (9.0) than Moroberekan (4.7) on day 42 of exposure to salt stress (Table 1).

5 Out of the 32 RILs, 17 had tillers plant ${ }^{-1}$ greater than CO39 (Fig. 1b). Shoot water $\left(\mathrm{g} \mathrm{g}^{-1} \mathrm{DW}\right)$ of parents and all RILs was reduced by salinity (Table 1), but the effect of Salinity $\times$ RILs interaction was not significant $(\mathrm{p}=0.07)$ (Suppl. Table 2).

In Study-1, leaf injury for Moroberekan was greater than CO39 on day 21 (Table 1). However there was no correlation between injury at day 21 and growth components on day 42 other than tiller number and shoot water content (Table 2) suggesting that the injury had until then little effect on biomass production, but might predict a decrease in growth rate. This was borne out by the finding that injury at day 42 correlated negatively with all growth components except for shoot dry weight (Table 2).

In Study-2, the parents and 120 RILs were grown in $100 \mathrm{mM} \mathrm{NaCl}$ for 42 days without a control treatment. On day 42, shoot fresh and dry weights of CO39 were 167 and 104\% respectively higher than Moroberekan (Table 3). This confirms CO39 as the more salt tolerant cultivar as its biomass was less than Moroberekan in the absence of salinity. The results of the first study indicated that tiller number and shoot water can be used as an index of salt tolerance. The shoot water content was higher in CO39 (2.8 $\left.\mathrm{g} \mathrm{g}^{-1} \mathrm{DW}\right)$ than in Moroberekan $\left(1.9 \mathrm{~g} \mathrm{~g}^{-1} \mathrm{DW}\right)$ and varied between 1.42 and $3.61 \mathrm{~g} \mathrm{~g}^{-1}$ in RIL population (Table 3). Tillers plant ${ }^{-1}$ were higher in CO39 (15.0) than Moroberekan (5.0). The number of tillers plant ${ }^{-1}$ ranged between 4.5 and 16.5 in the RIL population (Table 3).

In Study-2, the overall appearance was more affected in Moroberekan than CO39 as shown by chlorophyll loss and injury scores (Table 3). The phenotypic differences in parental varieties and RILs in response to salt stress can be further seen in pictures taken on day 42 (Suppl. Fig. 2). Chlorophyll concentration in the upper leaves on day 42 was higher in CO39 than Moroberekan (39 versus 13 SPAD units), and ranged between 10 and 42 in the RIL population (Table 3). Injury measured on day 21 was higher in Moroberekan (3.7) than CO39 (1.4) and ranged between 1 and 3.8 for the RILs, and correlated significantly with tillers, shoot water, and even 
score than on day 21 (Table 3) but the correlations with all growth components were higher than at the earlier time of measurement (Table 4).

\section{Variation in ion accumulation in CO39, Moroberekan and RILs}

In Study-1, $\mathrm{Na}^{+}$accumulation in the blade of recently fully expanded leaves at day 21 was 4 fold lower in CO39 (15 mM in leaf sap) than Moroberekan (64 mM) in the saline treatment (Table 1). Under salinity treatment, three out of 32 RILs had $\mathrm{Na}^{+}$concentration higher than Moroberekan), whereas in 14 RILs the $\mathrm{Na}^{+}$concentration was even lower than CO39, showing transgressive segregation towards $\mathrm{CO} 39$, the low $\mathrm{Na}^{+}$parent variety (Suppl. Fig. 1b). The analysis of variance revealed that treatments, RILs and Salinity $\times$ RILs interaction had highly significant $(\mathrm{p}<0.01)$ effects on $\mathrm{Na}^{+}$concentrations of the leaf blades (Supplemental Table 1). Leaf $\mathrm{K}^{+}$was very much higher in CO39 than Moroborekan, being $363 \mathrm{mM}$ versus $263 \mathrm{mM}$ in the control treatment, and only a little less in the salt treatment (Table 1). Under salinity, two out of 32 RILs had $\mathrm{K}^{+}$ concentration higher than CO39, whereas, six RILs had values of $\mathrm{K}^{+}$concentration less than Moroberekan, showing an approximate normal frequency distribution for the above trait (Suppl. Fig. 3a). There was a highly significant negative correlation of $\mathrm{Na}^{+}$with leaf $\mathrm{K}^{+}$concentration and $\mathrm{K}^{+} / \mathrm{Na}^{+}$on day 21 of salt stress (Table 2). CO39 showed about a nine-fold greater $\mathrm{K}^{+} / \mathrm{Na}^{+}$ ratio than Moroberekan under salinity stress (Table 1). Eleven out of 32 RILs maintained values of $\mathrm{K}^{+} / \mathrm{Na}^{+}$ratio even greater than the high parent CO39 (Suppl. Fig. 3b). Differences in the $\mathrm{K}^{+} / \mathrm{Na}^{+}$ratio of expanded leaves were highly significant $(\mathrm{p}<0.01)$ in the case of treatments, RILs and Salinity $\times$ RILs interaction (Suppl. Table 1). In summary, there was a significant increase in leaf $\mathrm{Na}^{+}$under salinity (Table 1 ) but the decrease in $\mathrm{K}^{+}$was not significant. $\mathrm{K}^{+}$concentrations increased in many RILs after salt stress.

In Study-2, both the leaf blade and leaf sheath $\mathrm{Na}^{+}$concentrations were measured on day 7 and 21 of salt stress in the most recent fully expanded leaves. The leaf sheath had a much higher $\mathrm{Na}^{+}$ concentration than the leaf blade, especially at the later time of sampling of 21 days (Table 3, Fig. 4a). The increase over time of $\mathrm{Na}^{+}$in the leaf blades was negligible for $\mathrm{CO} 39$ but large for Moroberekan (Fig. 4a). In the leaf sheath, the $\mathrm{Na}^{+}$increased by 2 -fold in $\mathrm{CO} 39$, and 3 -fold in Moroberekan. $\mathrm{K}^{+}$in the expanded leaf blades and sheaths was higher in CO39 than Moroberekan on 21 of salt stress (Table 3). On day 21 the $\mathrm{K}^{+}$concentration in the leaf sheaths was even higher 
in CO39 compared to its concentration on day 7 of salt stress (data not shown). With $\mathrm{K}^{+} / \mathrm{Na}^{+}$ ratios with increase in exposure time of salt stress from 7 to 21 days, there were reductions in both CO39 and Moroberekan; however the reductions were greater in Moroberekan than CO39 (Table 3 and Fig. 4b).

\section{Correlations between ion accumulation, growth attributes and leaf injury}

In Study-1, there was no correlation between leaf $\mathrm{Na}^{+}$measured on day 21 and injury scored on that day, but the correlation with injury scored on day 42 was highly significant ( $r=0.689)$ (Table 2, Fig. 2). This indicates that most of the leaf injury is due to accumulation of toxic concentrations of $\mathrm{Na}^{+}$, particularly in the fully expanded leaves. Leaf $\mathrm{K}^{+}$had a significant negative correlation with injury on day $42(\mathrm{r}=-0.532)$, suggesting that $\mathrm{K}^{+}$reduced the toxic effects of $\mathrm{Na}^{+}$by improving $\mathrm{K}^{+} / \mathrm{Na}^{+}$ratio of leaves under salt stress (Table 1 ). $\mathrm{Na}^{+}$concentrations on day 21 were not significantly correlated with SFW, SDW, SFW\%C or SDW\%C, however, correlations with tillers plant ${ }^{-1}$ and shoot water were significant (Table 2). Leaf $\mathrm{K}^{+}$showed positive and highly significant correlations with SFW, SDW and tillers plant ${ }^{-1}$ but not when SFW or SDW was expressed as \% of the controls (Table 2).

In Study-2, ion and injury measurements were made on day 7, as well as on day 21 . There was no injury to leaves on day 7, injury started on day 21 , and became severe on day 42 of salt stress, as shown in the photographs in Suppl. Fig. $2 \mathrm{Na}^{+}$in the leaf blade on day 21 correlated with injury on that day $(\mathrm{r}=0.35)$ and more strongly with injury on day $42(\mathrm{r}=0.71)$. This indicates that $\mathrm{Na}^{+}$concentrations even when not yet toxic are predictive of subsequent injury. Likewise $\mathrm{Na}^{+}$on day 7 although low and not associated with injury on day 7 or day 21 , was associated with injury on day $42(\mathrm{r}=0.32) . \mathrm{Na}^{+}$on day 7 was negatively correlated with all growth components, although the correlations were not as high as $\mathrm{Na}^{+}$on day 21 (Table 4). The correlation of $\mathrm{K} / \mathrm{Na}$ with growth components was not as great as $\mathrm{Na}^{+}$(Table 4). It is therefore assumed that injury is mainly because of accumulation of $\mathrm{Na}^{+}$in leaves and had a significant effect on shoot fresh and dry weights under salinity stress.

$\mathrm{Na}^{+}$concentrations in the sheath had a similar relation to injury and growth components (Suppl. Table 2a; Fig. 7a) as did $\mathrm{Na}^{+}$in the leaf (Table 4). $\mathrm{K}^{+}$concentrations in the sheath at day 7 had similar relationships to growth components as did $\mathrm{K}^{+}$in the leaf, but on day 21 there were much 
stronger and positive correlations with all growth components and stronger negative correlations with leaf injury (Suppl. Table 2a). The $\mathrm{K}^{+} / \mathrm{Na}^{+}$ratio of leaf sheaths had a significant effect on the number of tillers, SPAD and SDW but not on SFW and shoot water on day 7 (Suppl. Table 2a; Fig. 7b). Similarly, the $\mathrm{K}^{+} / \mathrm{Na}^{+}$ratio of leaf sheaths exerted significant and positive effects on all growth attributes except shoot water and leaf injury on day 21 . The relationship was significant and negative with injury on day 42 (Suppl. Table 2a; Suppl. Fig.4b).

\section{Discussion}

\section{Mechanisms of salt tolerance, and selectable traits}

When plants are first exposed to salinity, the rapid reductions in growth are due to the osmotic effect of the salt concentration in the root medium which changes the water status of plants, and affects the young growing leaves via root signals. Later, the buildup of $\mathrm{Na}^{+}$to toxic levels in older leaves affects growth due to lack of photosynthate supply to growing tissues (Munns 1993; Munns 2002). This was described as a two-phase growth response to salinity (Munns 1993). In a prolonged study with various wheat genotypes differing in the ability to exclude $\mathrm{Na}^{+}$, differences in growth rates between genotypes were not observed until $20 \%$ of the leaves were injured, but by then growth rates were very much less than controls due to the osmotic effect of the salt. In the two experiments reported here, there was no sign of leaf injury by day 7 , so $\mathrm{Na}^{+}$had not reached toxic levels by that time yet growth rates were already obviously severely reduced (data not shown). Only until day 21 in both studies was injury considerable, by which time biomass was already considerably affected. TANVEER - DID YOU HAVE OBSERVATIONS AT DAY $14 ? ? ?$

The aim of this study was to compare different selectable traits for reliable detection of salinity tolerant lines of rice and in particular to quantify the relationships between $\mathrm{Na}^{+}$exclusion, leaf injury, and growth under salt stress. Plants would need to be grown for a long enough time to allow the accumulation of $\mathrm{Na}^{+}$to toxic concentrations to affect growth via reduction in photosynthate supply. This is especially difficult with large numbers of lines, and when comparing lines that differ in intrinsic biomass production in the absence of salinity. The CO39 $\times$ Moroberekan RIL population was used alongside both parents. Although Moroberekan had a higher $\mathrm{Na}^{+}$accumulation, it was more vigorous and produced twice the biomass of CO39 
over time - and so it was expected that there might be segregation for the several genes responsible for $\mathrm{Na}^{+}$exclusion with combinations of genes affecting dry weight production.

As a proxy for salt tolerance we measured the percent biomass production in saline versus nonsaline control conditions after 42 days under $100 \mathrm{mM} \mathrm{NaCl}$, and assessed the correlation of this trait with $\mathrm{Na}^{+}$and $\mathrm{K}^{+}$concentrations in leaves and with leaf injury for 32 RILs. For a larger number of RILs (120) we measured the biomass production and leaf injury in the presence of $100 \mathrm{mM} \mathrm{NaCl}$ (without controls - due to the unfeasibility of maintain plants growing at optimum growth rates for such a large number of genotypes) and assessed the relationship of leaf blade and sheath $\mathrm{Na}^{+}$and $\mathrm{K}^{+}$with injury. We also measured the tillers per plant ${ }^{-1}$, chlorophyll concentration with a SPAD meter, and shoot water content on a dry weight basis. We have focused on recognizing traits which could be more useful for reliable selection from a large number of individuals with limited resources and time. We discuss the suitability of \% SDW, \% SFW, tillers plant ${ }^{-1}$ as index of salt tolerance and a number of morpho-physiological traits (shoot water content, leaf injury scores, SPAD-chlorophyll, leaf blade and sheath $\mathrm{Na}^{+}, \mathrm{K}^{+}$and $\mathrm{K}^{+} / \mathrm{Na}^{+}$) for selecting salt tolerant germplasm in large populations of rice.

This study confirmed CO39 as a more salt tolerant rice cultivar than Moroberekan, and identified five of 32 RILs with salt tolerance (\% control biomass) better than CO39. In addition, several RILs were shown in the second study as having even lower $\mathrm{Na}^{+}$accumulation than $\mathrm{CO} 39$, along with very high tillers plant ${ }^{-1}$ and shoot biomass, indicating that these would have a greater salt tolerance (\% control biomass).

Indica rice has the ability to exclude $\mathrm{Na}^{+}$to avoid toxic accumulation in leaves, and to absorb more $\mathrm{K}^{+}$to maintain the $\mathrm{Na}^{+} / \mathrm{K}^{+}$balance in the shoot (Gregorio and Senadhira 1993). The salt tolerant Indica variety (CO39) in this study also has ability to exclude $\mathrm{Na}^{+}$from the shoot to a greater extent than the sensitive Japonica (Moroberekan) in which $\mathrm{Na}^{+}$levels were 4 fold more than those in Indica rice. Moreover, the tolerant Indica rice also had the ability to absorb more $\mathrm{K}^{+}$to maintain the $\mathrm{Na}^{+} / \mathrm{K}^{+}$balance in the shoot.

The study showed that: $\mathrm{Na}^{+}$exclusion (low $\mathrm{Na}^{+}$accumulation in the leaf blades) was strongly associated with leaf injury, and is presumed to be the main cause of it. $\mathrm{Na}^{+}$accumulation was useful in identifying RILs with higher salt tolerance. Injury of top leaves was useful in the absence of growth rate measurements in relation to the growth in control conditions. However 
there was no correlation between $\mathrm{Na}^{+}$exclusion and growth even at day 42 in Study-1 although there was in Study-2. Possibly if Study-1 was conducted for a longer period of time then the same results as for Study-2 would have been found. It appears that plants might have grown faster and differences in salt tolerance became more distinct in Study-2, as in Study 1 CO39 reached $17.5 \mathrm{~g}$ with 9 tillers under salt but in Study-2 it reached $29.5 \mathrm{~g}$ with 15 tillers. In contrast, Moroborekan had the same tiller number (5) but a lower SFW in the second study (Table 1). This illustrates the importance of experimental replication when assessing a 8 quantitative trait, as it is difficult to control all environmental variables within a glasshouse over different seasons, and genotype x environment interactions are so strong.

Several earlier papers using a number of different rice cultivars or genotypes have shown a correlation between genetic differences in the $\mathrm{Na}^{+}$concentration in a leaf and salt tolerance as expressed by \% control biomass production (Haq et al. 2008), plant survival (Yeo and Flowers 1984; Yeo and Flowers 1986), or the degree of injury or leaf death under salinity stress (Yeo et al. 1990; Gregorio et al. 1997).

The questions we addressed were: how useful are $\mathrm{Na}^{+}$concentrations and their QTLs as traits for selection for salt tolerance? What is the mechanism by which $\mathrm{Na}^{+}$accumulation rate affects growth rate and thereby yield? Can molecular markers for a QTL for $\mathrm{Na}^{+}$be used to screen for salt tolerance, in the absence of data on biomass production in saline versus non-saline conditions?

To assess the level of leaf injury, scoring can be a useful and inexpensive indicator. The score used here was 1-4, although 1-5 (Haq et al. 2010) and 1-9 (Platten et al. 2013) have been successfully used. In the second experiment, chlorophyll concentration was measured with the SPAD meter, which might be expected to give more precise quantitative results, but the correlations between SPAD and the sensitive growth attributes and with $\mathrm{Na}^{+}$were very similar to those with injury (Table 4), suggesting that visual scores are a reliable substitute for chlorophyll estimatations. 
Significant positive correlations of $\mathrm{Na}^{+}$with leaf injury scores in these studies indicates that $\mathrm{Na}^{+}$

2 buildup to a toxic level is the main cause of leaf senescence particularly of the older leaves at later stages of salt stress. Lin et al. (2004) also correlate $\mathrm{Na}^{+}$accumulation with leaf salt damage

4 under high salinity in rice.

5 On day 42 of salt stress there was large variation in salt injury to rice plants (Fig. 10a and 10b).

6 Moroberekan experienced more leaf injury than CO39 (Fig. 10a). This was most likely due to

7 toxic accumulation of $\mathrm{Na}$ in the leaf blade. In Study-1, most of the leaf damage was due to

8 accumulation of toxic levels of $\mathrm{Na}^{+}$in the expanded leaf as indicated by the strong correlations

9 between $\mathrm{Na}^{+}$and injury Score-2 (Fig. 3a and 9). The correlation of salinity-induced leaf injury

10 with whole-plant and leaf blade $\mathrm{Na}^{+}$concentrations was high in nearly all accessions of Oryza

11 sativa and Oryza glaberrima (Platten et al. 2013).

12 There are two other explanations for the onset of leaf injury: that it was due to toxic accumulation in the leaf sheath which reached a higher level first, or that it was due to the salt around the roots ie osmotic stress.

Sheath $\mathrm{Na}^{+}$concentrations were three times the leaf blade, and approached toxic concentrations earlier in the leaf sheath. The high concentration of $\mathrm{Na}^{+}$in sheath tissue than leaf blade of CO39

17 (salt tolerant variety) under salt stress may also be due to removal of $\mathrm{Na}^{+}$from the transpiration stream and its deposition in xylem parenchyma cells to reduce delivery into the shoots. Four fold difference in $\mathrm{Na}^{+}$accumulation between sheath and leaf blade in rice was also documented by Yeo and Flowers (1982). The leaf sheath concentration was always higher on a tissue water basis, and incidentally much higher again on a dry weight basis (the water of the sheath being

22 almost twice as high as the blade). It is possible that this leaf sheath concentration is responsible 23 for the onset of injury seen in the leaf blade. Platten et al (2013) found sheath:blade ratios of 2-3 24 depending on genotype. Based on the visual injury as seen in the photographs from Study-2, when the conc. of $\mathrm{Na}^{+}$in the expanded leaves remained below $20 \mathrm{mM}$ and in sheath below 65 $\mathrm{mM}$ in about three weeks' time under salt stress there was no damage to leaves and leaves remain health and green even after 42 days exposure. However when the $\mathrm{Na}^{+}$in expanded leaves accumulated above $50 \mathrm{mM}$ and in sheath crossed $100 \mathrm{mM}$ in about three weeks' time it caused a significant damage to plant and injury was further increased with increase in $\mathrm{Na}^{+}$accumulation. 
1 Leaf injury might be promoted by the osmotic effects of the salt outside the roots, accelerating

2 leaf senescence as it does water stress caused by dry soils. In Study-2, where $\mathrm{Na}^{+}$was measured

3 at two times the correlation between injury and $\mathrm{Na}^{+}$of expanded leaves changed with time and it

4 was higher on day 21 compared to correlation on day 7 of stress. This means under salt stress at

5 least some time is required for $\mathrm{Na}^{+}$to accumulate in the expanded leaf and to affect growth,

6 supporting the two-phase growth model under salinity put forward by Munns et al (1995).

7 Therefore it can be assumed that much of the reduction in growth at earlier stage of stress may be

8 due to osmotic and other effects.

Role of leaf $\mathrm{K}^{+}$in salt tolerance

11 It has been commonly observed that the accumulation of $\mathrm{Na}^{+}$in shoot tissues is often 12 accompanied by a reduction in shoot $\mathrm{K}^{+}$concentrations, resulting in decreased $\mathrm{K}^{+} / \mathrm{Na}^{+}$ratios 13 (Asch et al. 2000). Salinity results in a reduction of leaf $\mathrm{K}^{+}$concentration, however, this 14 reduction was less in CO39 compared with Moroberekan under salt stress. $\mathrm{K}^{+}$concentration was 15 much higher (27\%) in CO39, when compared with Moroberekan in non saline conditions (Table 1), and the $\mathrm{K}^{+}$was $28 \%$ higher in the leaves of CO39 than Moroberekan at 21 days of salt stress.

17 Interestingly, In case of Study-2, again CO39 exhibited higher $\mathrm{K}^{+}$concentration in the sap of all 18 tissue types sampled at both salt stresses, however, differences were more pronounced at 21 days than 7 days salt stress. This resulted in a higher $\mathrm{K}^{+} / \mathrm{Na}^{+}$ratio in these studies (Suppl. Table 2). A good supply of $\mathrm{K}^{+}$to plants can minimize injurious effects of high $\mathrm{Na}^{+}$under salinity. Salt tolerant crop varieties also show special ability to maintain high $\mathrm{K}^{+} / \mathrm{Na}^{+}$ratio in cell cytosol, when exposed to $\mathrm{NaCl}$ salinity (Carden et al. 2003; Golldack et al. 2003; Peng et al. 2004). Differences between susceptible Japonica and Indica rice types were highly significant for all growth parameters and shoot $\mathrm{Na}^{+}$but not for shoot $\mathrm{K}^{+}$concentration (Lee et al. 2003). Similarly, in Japonica rice shoot $\mathrm{K}^{+}$showed no relation to salt tolerance but tolerant Indica varieties maintained very high $\mathrm{K}^{+}$in the shoot (Lee and Senadhira 1996) supporting our results. Likewise,

27 Akhtar (2002) also found negative and significant correlation between $\mathrm{K}^{+}$in the sap of leaf blade 28 and SFW. 
1 Partly the differences in measured $\mathrm{Na}^{+}$ion concentrations were also caused by greater 2 dehydration of the leaves of Moroberekan, and this was almost entirely responsible for the 3 increase in leaf $\mathrm{K}^{+}$concentrations (Akhtar 2002).

5 Useful Morphological and Physiological traits for screening in rice

6 The growth measurements or physiological traits depend on the objective of screening. If the objective is to develop varieties for good yield on salt affected lands absolute yield or biomass at anthesis is the appropriate criterion of selection. However, if the purpose of selection is to identify the better sources of salt tolerance to further use in breeding programs by the breeders then SDW \% of control would be a more valuable index to use for screening against salinity. However, this is not possible for large populations. Salt tolerance with a large population or number of genotypes is not feasible because of the space required to grow plants in the control treatment with enough space $=$ light to give optimal growth and sufficient replications to produce a meaningful statistical value. This study showed that for experiments when genotype numbers preclude the growth in control conditions as well, and when growth in that condition varies between parents and hence between genotypes, then tiller number and shoot water content are sensitive traits. This of course would not be valid if the parents differed in tiller number in control conditions. Then shoot water content, which reflects biomass as well as desiccation to upper leaves caused by injury is valid. These traits are recommended as they reflect the growth of the plant during the period of salinity and hence productive biomass that is related to yield.

However injury as a trait also has a place as it can be measured easily and non-destructively, on the top 2-3 leaves either by visual scoring by chlorophyll concentration with a SPAD meter. It is highly correlated with $\mathrm{Na}$ accumulation, and so is a useful trait for identifying QTLs for $\mathrm{Na}$ exclusion. It also can be predictive on future biomass production.

An aspect which might have been neglected to some extent is the environmental factors during the process of selection. The factors such as temperature, growth stage and humidity have wide spread effects on salt tolerance of plants. They need to be considered as integral components of the selection process. The use of marker assisted selection (MAS) also provides a great potential for screening but depends on the availability of tightly linked markers having universal 
1 applicability. The one major advantage of these markers over morpho-physiological markers is

2 that they are not affected by the growth stage and the environmental conditions and are large in

3 number.

4 In conclusion, this study confirmed that plants need to be grown for a lengthy period of time 5 before genetic differences in salt tolerance appear, and before leaf injury is an indicator of salt

6 tolerance. It showed that short-term exposure of even 21 days may not be enough to pick genetic

7 differences, and that exposure of more than 42 days is required to get valuable information. We

8 have also shown that much of the growth reduction, which was previously thought to be due to

9 toxic ions, was due to the osmotic effects of the salt around the roots, supporting the two phase

10 model of salt stress response. The study showed that high $\mathrm{Na}^{+}$accumulation in the leaf blades

11 was strongly associated with leaf injury and is presumed to be the main cause of it. Injury of top

12 leaves was useful in predicting the ultimate salt tolerance of the RILs.

\section{Acknowledgements}

15 Financial support for this work from Higher Education Commission (HEC) of Pakistan and EU 16 Commission is thankfully acknowledged. The RILs were supplied by Dr. Adam Price 17 (University of Aberdeen) and Dr. Brigitte Courtois (CIRAD, Montpellier, France).

\section{References}

20 Akhtar N (2002) Salt tolerance studies in rice (Oryza sativa L.) Ph.D. Thesis. School of Biological Sciences, Bangor University, Wales, UK. Research 29, 75-112.

24 Asch F, Dingkuhn M, Dorffling K, Miezan K (2000) Leaf K/Na ratio predicts salinity induced yield loss in irrigated rice. Euphytica 113, 109-118. 17-42. 
Ashraf M, Harris PJ (2004) Potential biochemical indicators of salinity tolerance in plants. Plant Science 166, $3-16$.

Bonilla P, Dvorak J, Mackill D, Deal K, Gregorio G (2002) RFLP and SSLP mapping of salinity tolerance genes in chromosome 1 of rice (Oryza sativa L.) using recombinant inbred lines. Philippine Agricultural Scientist 85, 68-76.

Bhumbla DR, Abrol IP (1978) Saline and sodic soils. Proceedings of the IRRI Symposium on Soils and Rice (International Rice Research Institute, Manila, Philippines) pp. 719-738.

Byrt CS, Platten JD, Spielmeyer W, James RA, Lagudah ES, Dennis ES, Tester M, Munns R (2007) HKT1;5-like cation transporters linked to $\mathrm{Na}^{+}$exclusion loci in wheat, $\mathrm{Nax} 2$ and Knal. Plant Physiology 143, 1918-1928.

Carden DE, Walker DJ, Flowers TJ, Miller AJ (2003) Single-cell measurements of the contributions of cytosolic $\mathrm{Na}^{+}$and $\mathrm{K}^{+}$to salt tolerance. Plant Physiology 131, 676-83.

Champoux M, Wang G, Sarkarung S, Mackill D, O’Toole J, Huang N, McCouch SR (1995) Locating genes associated with root morphology and drought avoidance in rice via linkage to molecular markers. Theoretical and Applied Genetics 90, 969-981.

Chinnusamy V, Jagendorf A, Zhu JK (2005) Understanding and improving salt tolerance in plants. Crop Science 45, 437-448.

Cotsaftis O, Plett D, Shirley N, Tester M, Hrmova M (2012) A Two-Staged Model of $\mathrm{Na}^{+}$Exclusion in Rice Explained by 3D Modeling of HKT Transporters and Alternative Splicing. PLoS ONE 7(7), e39865.

Davenport R, James RA, Zakrisson-Plogander A, Tester M, Munns R (2005) Control of sodium transport in durum wheat. Plant Physiology 137, 807-818.

Davenport RJ, Munoz-Mayor A, Jha D, Essah PA, Rus A, Tester M (2007) The $\mathrm{Na}^{+}$transporter AtHKT1;1 controls retrieval of $\mathrm{Na}^{+}$from the xylem in Arabidopsis. Plant, Cell and Environment 30, 497-507.

Davies WJ, Zhang J (1991) Root signals and the regulation of growth and development of plants in drying soil. Annual Review Plant Physiology Plant Molecular Biology 42, 55-76.

Epstein, E. 1994. The anomaly of silicon in plant biology. Proc. Natl. Acad. Sci. USA. 
Flowers TJ, Hajibagheri MA, Yeo AR (1991) Ion accumulation in the cell walls of rice plants growing under saline conditions: evidence for the Oertli hypothesis. Plant, Cell \& Environment 14, 319-325.

Flowers TJ, Troke PF, Yeo AR (1977) The mechanism of salt tolerance in halophytes. Annual Reviews of Plant Physiology 28, 89-121.

Flowers TJ, Yeo AR (1986) Ion relations of plants under drought and salinity. Australian Journal of Plant Physiology. 13, 75-91.

Garciadeblas B, Senn ME, Ban uelos MA, Rodrı guez-Navarro A (2003) Sodium transport and HKT transporters: the rice model. The Plant Journal 34, 1-14.

Gassmann W, Rubio F, Schroeder JI (1996) Alkali cation selectivity of the wheat root highaffinity potassium transporter HKT1. The Plant Journal 10, 869-882.

Golldack D, Quigley F, Michalowski CB, Kamasani UR, Bohnert HJ (2003) Salinity stress tolerant and sensitive rice (Oryza sativa L.) regulate AKT1-type potassium channel transcripts differently. Plant Molecular Biology 51, 71-81.

Gong, H.J., D.P. Randall and T.J. Flowers. 2006. Silicon deposition in the root reduces sodium uptake in rice (Oryza sativa L.) seedlings by reducing bypass flow. Plant Cell and Environment 29, 1970-1979.

Gorham J, Bridges J, Dubcovsky J, Dvorak J, Hollington PA, Luo MC, Khan JA (1997) Genetic analysis and physiology of a trait for enhanced $\mathrm{K}^{+} / \mathrm{Na}^{+}$discrimination in wheat. New Phytologist 137, 109-116.

Green RE, Cornell SJ, Scharlemann JPW, Balmford A (2005) Farming and the fate of wild nature. Science 307, 550-554.

Gregorio GB, Senadhira D (1993) Genetic analysis of salinity tolerance in rice (Oryza sativa L.). Theoretical and Applied Genetics 86, 333-338.

Gregorio GB, Senadhira D, Mendoza RD (1997) Screening rice for salinity tolerance. IRRI Discussion Paper Series No. 22. International Rice Research Institute, Manila, Philippines. 
Gregorio GB, Senadhira D, Mendoza RD, Manigbas NL, Roxas JP, Guerta CQ (2002) Progress in breeding for salinity tolerance and associated abiotic stresses in rice. Field Crops Research 76, 91-101.

Haq TU, Akhtar J, Gorham J, Steele KA, Khalid M (2008) Genetic mapping of QTLs, controlling shoot fresh and dry weight under salt stress in rice (Oryza sativa L.) cross between CO39×Moroberekan. Pakistan Journal of Botany 40, 2369-2381.

Haq TU, Gorham J, Akhtar J, Akhtar N, Steele KA (2010) Dynamic QTL for salt stress components on chromosome 1 of rice. Functional Plant Biology 37, 634-645.

Haro R, Ban uelos, MA, Senn ME, Barrero-Gil J, Rodrı guez-Navarro A (2005) HKT1 mediates sodium uniport in roots. Pitfalls in the expression of HKT1 in yeast. Plant Physiology 139, 1495-1506.

Hoagland DR, Arnon DI (1950) The water culture method for growing plant without soil. California Agriculture Experiment Station Circular 347, pp. 39.

Horie T, Karahara I, Katsuhara M (2012) Salinity tolerance mechanisms in glycophytes: An overview with the central focus on rice plants. Rice 5, 1-18.

Horie T, Yoshida K, Nakayama H, Yamada K, Oiki S, Shinmyo A (2001) Two types of HKT transporters with different properties of $\mathrm{Na}^{+}$and $\mathrm{K}^{+}$transport in Oryza sativa. The Plant Journal 27, 129-138.

Huang S, Spielmeyer W, Lagudah ES, James RA, Platten JD, Dennis ES, Munns R (2006) A sodium transporter (HKT7) is a candidate for Nax1, a gene for salt tolerance in durum wheat. Plant Physiology 142, 1718-1727.

Jacoby B (1999) Mechanisms involved in salt tolerance of plants, In: M. Pessarakli (Ed.), Handbook of Plant and Crop Stress, $2^{\text {nd }}$ ed., Marcel Dekker, New York, 1999, pp. $97-$ 123.

Kader MA (2006) Salt Stress in Rice: Adaptive mechanisms for cytosolic sodium homeostasis: $\mathrm{PhD}$ thesis Swedish University of Agricultural Sciences Uppsala, Sweden. 
Kader MA, Lindberg S (2005) Uptake of sodium in protoplasts of salt-sensitive and salt tolerant cultivars of rice, Oryza sativa L. determined by the fluorescent dye SBFI. Journal of Experimental Botany 56, 3149-3158

Kader MA, Seidel T, Golldack D, Lindberg S (2006) Expressions of OsHKT1, OsHKT2 and OsVHA are differentially regulated under $\mathrm{NaCl}$ stress in salt-sensitive and salt tolerant rice (Oryza sativa L.) cultivars. Journal of Experimental Botany 57, 4257-4268.

Khan GS (1998) Soil salinity/sodicity status in Pakistan. Soil Survey of Pakistan, Lahore. pp. 59.

Lafitte HR, Ismail A, Bennett J (2004) Abiotic stress tolerance in rice for Asia: Progress and the future. In: New Directions for a Diverse Planet: Proceedings for the 4th International Crop Science Congress. (Eds. Fischer T, Turner N, Angus J, McIntyre L, Robertson M, Borrell A, et al.) The Regional Institute Ltd. The proceedings are available online at: www.cropscience.org.au/ icsc2004.

Lauchli A, Epstein E (1990) Plant responses to saline and sodic conditions. In: Agricultural salinity assessment and management (K.K. Tanji (ed)). ASCE manuals and reports on engineering practice No, 71. pp 113-137 ASCE New York

Laurie S, Feeney KA, Maathuis FJM, Heard PJ, Brown SJ, Leigh RA (2002) A role for HKT1 in sodium uptake by wheat roots. The Plant Journal 32, 139-149.

Lawrence WJC, Newell J (1939) 'Seed and potting composts'. (Allen and Unwin: London).

Lee KS, Choi WY, Ko JC, Kim TS, Gregoria GB (2003) Salinity tolerance of japonica and indica rice (Oryza sativa L.) at the seedling stage. Planta 216, 1043-1046.

Lindsay MP, Lagudah ES, Hare RA, Munns R (2004) A locus for sodium exclusion (Nax1), a trait for salt tolerance mapped in durum wheat. Functional Plant Biology 13, 1105-1114.

Lutts S, Guerrir G (1995) Peroxidase activities of two rice cultivars differing in salinity tolerance as affected by proline and $\mathrm{NaCl}$. Biologia Plantarum 37, 577-586.

Møller IS, Gilliham M, Jha D, Mayo GM, Roy SJ, Coates JC, Haseloff J, Tester M (2009) Shoot $\mathrm{Na}^{+}$exclusion and increased salinity tolerance engineered by cell type specific alteration of $\mathrm{Na}^{+}$transport in Arabidopsis. Plant Cell 21, 2163-2178. 
Munns R (2002) Comparative physiology of salt and water stress. Plant Cell and Environment 25, 239-250.

Munns R (2005) Genes and salt tolerance: bringing them together. New Phytologist 167, 645663.

Munns R, James RA, Läuchli A (2006) Approaches to increasing the salt tolerance of wheat and other cereals. Journal of Experimental Botany 57, 1025-1043.

Munns R, James RA, Xu B, Athman A, Conn SJ, Jordans C, Byrt CS, Hare RA, Tyerman SD, Tester M, Plett D, Gilliham M (2012) Wheat grain yield on saline soils is improved by an ancestral $\mathrm{Na}^{+}$transporter gene. Nature Biotechnology 30, 360-364.

Munns R, Schachtman D, Condon A (1995) The significance of a two-phase growth response to salinity in wheat and barley. Functional Plant Biology, 22, 561-569.

Munns R, Tester M(2008) Mechanisms of salinity tolerance. Annual Reviews in Plant Biology 59, 651-681.

Niones JM (2004) Fine mapping of the salinity tolerance gene on chromosome 1 of rice (Oryza sativa L.) using near isogenic lines. MSc Thesis, University of the Philippines, Los Baños, Laguna.

Parker DR, Norvell WA, Chaney RL (1995a) GEOCHEM-PC: a chemical speciation program for IBM and compatible personal computers. In $\mathrm{R} \mathrm{H}$ Loeppert et al., eds, Chemical Equilibrium and Reaction Models. Soil Science Society of America, Special Publication 42. Madison, WI, pp 253-269.

Peng S, Ismail AM (2004) Physiological basis of yield and environmental adaptation in rice. In: Physiology and biochemistry integration for plant breeding - Nguyen HT, Blum A, eds. New York: Marcel Dekker, Inc. 83-140.

Platten JD, Egdane JA, Ismail AM (2013) Salinity tolerance, $\mathrm{Na}^{+}$exclusion and allele mining of HKT1;5 in Oryza sativa and O. glaberrima: many sources, many genes, one mechanism? BMC Plant Biology 13, 32 
Plett D, Safwat G, Gilliham M, Møller IS, Roy S, Shirley N, Jacobs A, Johnson A, Tester M (2010) Improved salinity tolerance of rice through cell type-specific expression of AtHKT1;1. PLoS ONE 5(9): e12571.

Prasad SR, Bagali PG, Hittalmani S, Shashidhar HE (2000) Molecular mapping of quantitative trait loci associated with seedling tolerance to salt stress in rice (Oryza sativa L.). Current Science 78:162-164.

Ren ZH, Gao JP, Li LG, Cai XL, Huang W, Chao DY, Zhu MZ, Wang ZY, Luan S, Lin HX (2005) A rice quantitative trait locus for salt tolerance encodes a sodium transporter. Nature Genetics 37, 1141-1146.

Shabala L, Cuin TA, Newman I, Shabala S (2005) Salinity-induced ion flux patterns from the excised roots of Arabidopsis sos mutants. Planta 222, 1041-1050.

Shi HZ, Lee BH, Wu SJ, Zhu JK (2003) Overexpression of a plasmamembrane $\mathrm{Na}^{+} / \mathrm{H}^{+}$antiporter gene improves salt tolerance in Arabidopsis thaliana. Nature Biotechnology 21, 81-85.

Shi HZ, Quintero FJ, Pardo JM, Zhu JK (2002) The putative plasmamembrane $\mathrm{Na}^{+} / \mathrm{H}^{+}$antiporter SOS1 controls long-distance $\mathrm{Na}^{+}$transport in plants. Plant Cell 14, 465-477.

SPSS (2002) Statistical Package for Social Sciences (SPSS for Windows). Released 11.5.1. SPSS Inc. Chicago.

Szabolcs I (1989) Salt Affected Soils. CRC Press. Boca Raton. Florida. 274 p.

Tester M, Davenport R (2003) $\mathrm{Na}^{+}$tolerance and $\mathrm{Na}^{+}$transport in higher plants. Annals of Botany 91, 503-527.

Witcombe JR, Hollington PA, Howarth CJ, Reader S, Steele KA (2008) Breeding for abiotic stresses for sustainable agriculture. Philosophical Transactions of the Royal Society B: Biological Sciences 363(1492):703-716.

Wyn Jones RG, Brady CJ, Speirs J (1979) Ionic and osmotic relations in plant cells. In Recent Advances in the Biochemistry of Cereals. (Eds. D.L. Laidman R.G. Wyn Jones). Academic Press Inc. (London) Ltd. London UK. New York. p:63-103.

Wyn Jones RG, Gorham J (1983) Osmoregulation. Physiological Plant Ecology III, Encyclopedia of Plant Physiology. 12C: 35-58. 
1 Yeo AR, Flowers TJ (1982) Accumulation and localization of sodium ions with in the shoots of 2 rice (Oryza sativa) varieties differing in salinity resistance. Physiologia Plantarum 56, $3 \quad 343-348$.

4 Yeo AR, Flowers TJ (1984) Mechanisms of salinity resistance in rice and their role as 5 physiological criteria in plant breeding In. 'Salinity tolerance in plants'. (Eds RC Staples, GH Toenniessen) pp. 37-67. (Wiley: New York)

7 Yeo AR, Flowers TJ (1986) Salinity resistance in rice (Oryza sativa L.) and a pyramiding 8 approach to breeding for saline soils. Australian Journal of Plant Physiology 13, 161$9 \quad 173$.

10 Yeo AR, Yeo ME, Flowers SA, Flowers TJ. 1990. Screening of rice (Oryza sativa L.) genotypes 11 for physiological characters contributing to salinity resistance, and their relationship to 12 overall performance. Theoretical and Applied Genetics 79, 377-384.

13 Zeng L, Lesch SM, Grieve CM (2003) Rice growth and yield respond to changes in water depth 14 and salinity stress. Agriculture Water Management 59, 67-75. 

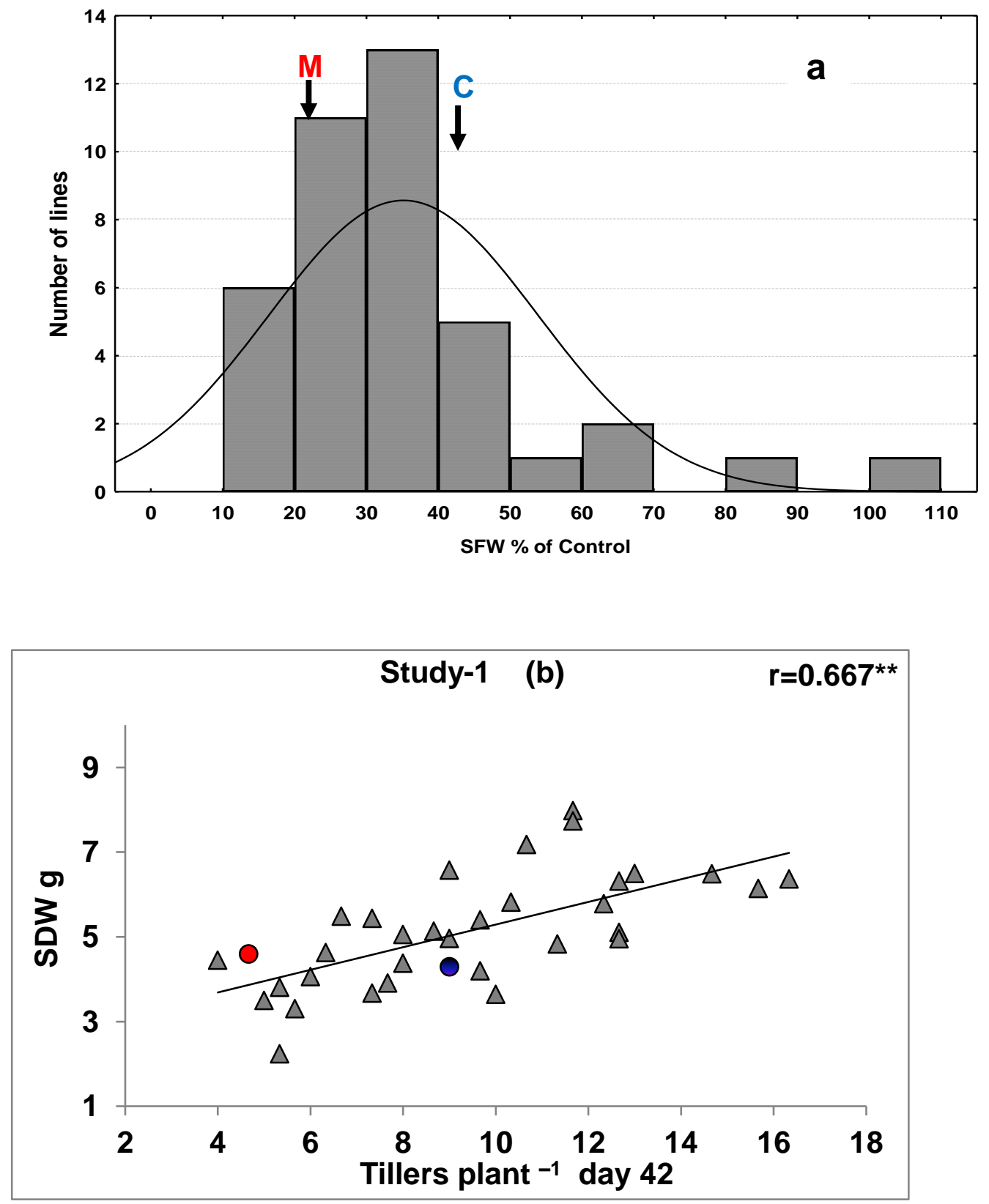

4

5 Fig.1. (a) Frequency distribution for shoot fresh weight after $42 \mathrm{~d}$ in $100 \mathrm{mM} \mathrm{NaCl}$ as $\%$ of 6 control for RIL population $(n=32)$ in Study-1. Normal curve for the distribution is also shown. The arrows indicate mean values for CO39 and Moroberekan. (b) Relationship between tiller's plant ${ }^{-1}$ and SDW on day 42 in $100 \mathrm{mM} \mathrm{NaCl}$. The red and blue circles indicate mean values for CO39 and Moroberekan respectively. $\mathrm{r}=$ Pearson's correlation coefficient (2- tailed) 


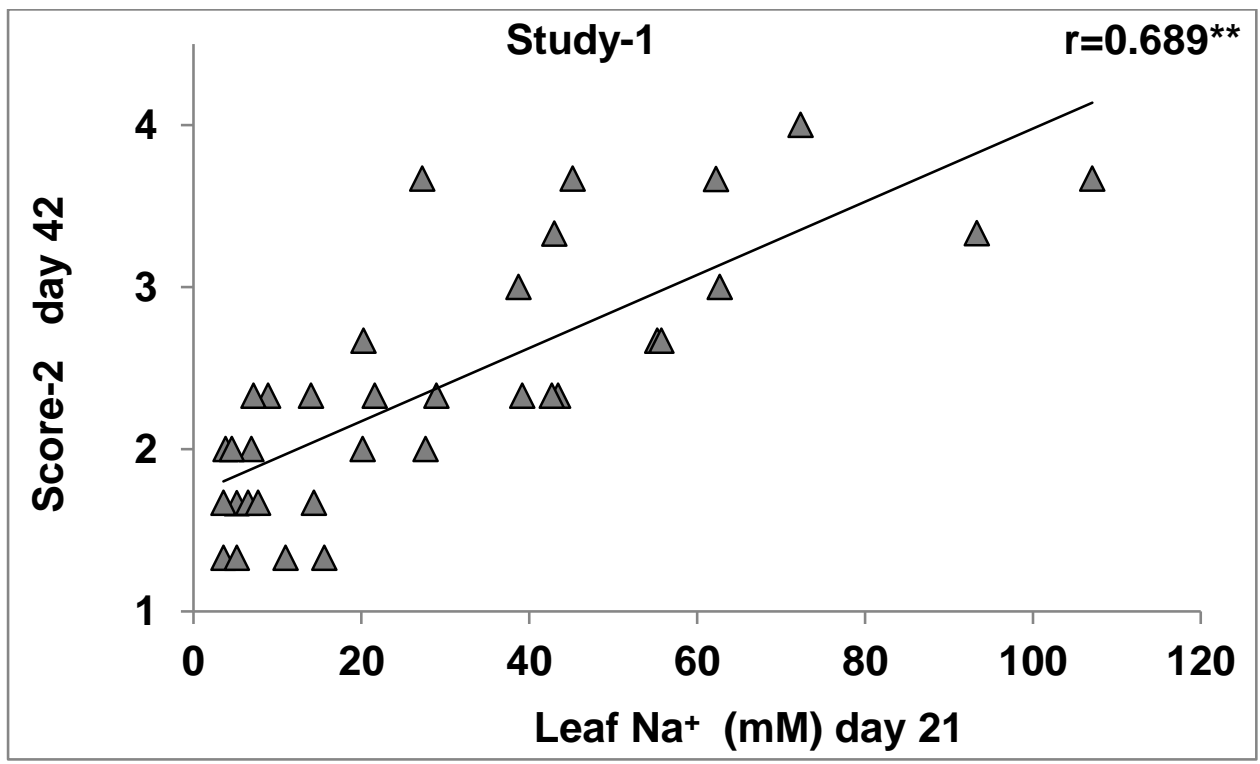

4

Fig.2. Relationship of leaf injury (Score-2) measured on day 42 with leaf blade sap $\mathrm{Na}^{+}$ measured on day 21 of salt stress in Study-1. $r=$ Pearson's correlation coefficient (2-tailed) 


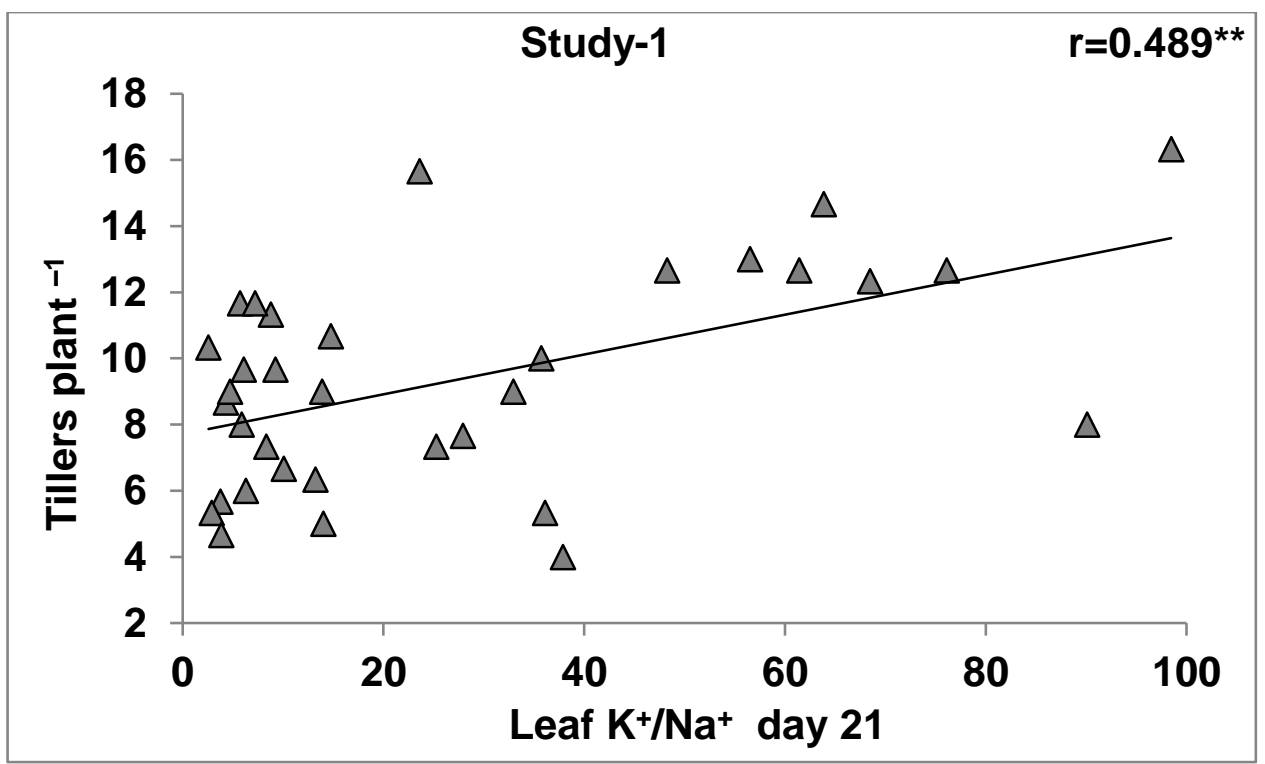

4

5 Fig.3. Relationships of leaf blade sap $\mathrm{K} / \mathrm{Na}$ with tillers plant ${ }^{-1}$ on day $21 / 42$ of salt stress in 6 Study-1. $r=$ Pearson's correlation coefficient (2-tailed) 

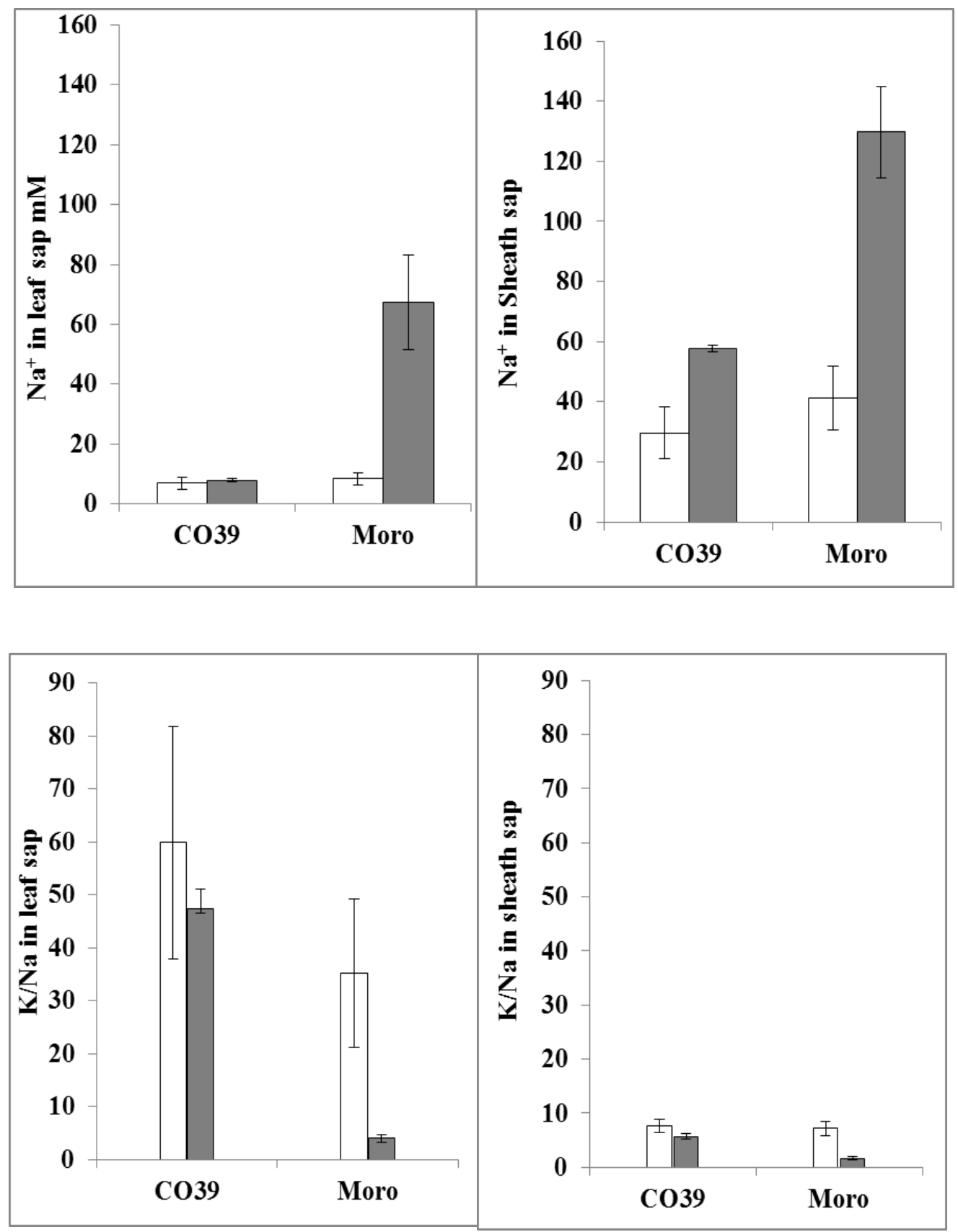

Fig.4. Change in (a) $\mathrm{Na}^{+}$concentration in leaf blade and leaf sheath (b) $\mathrm{K}^{+} / \mathrm{Na}^{+}$ratio of leaf blade and sheath sap on day 7 (open bars) and day 21 (black bars) in CO39 and Moroberekan under salt stress in Study-2 (Error bar shows SEM). Leaf and sheath $\mathrm{K}^{+}$ concentration values are in Table 3. 

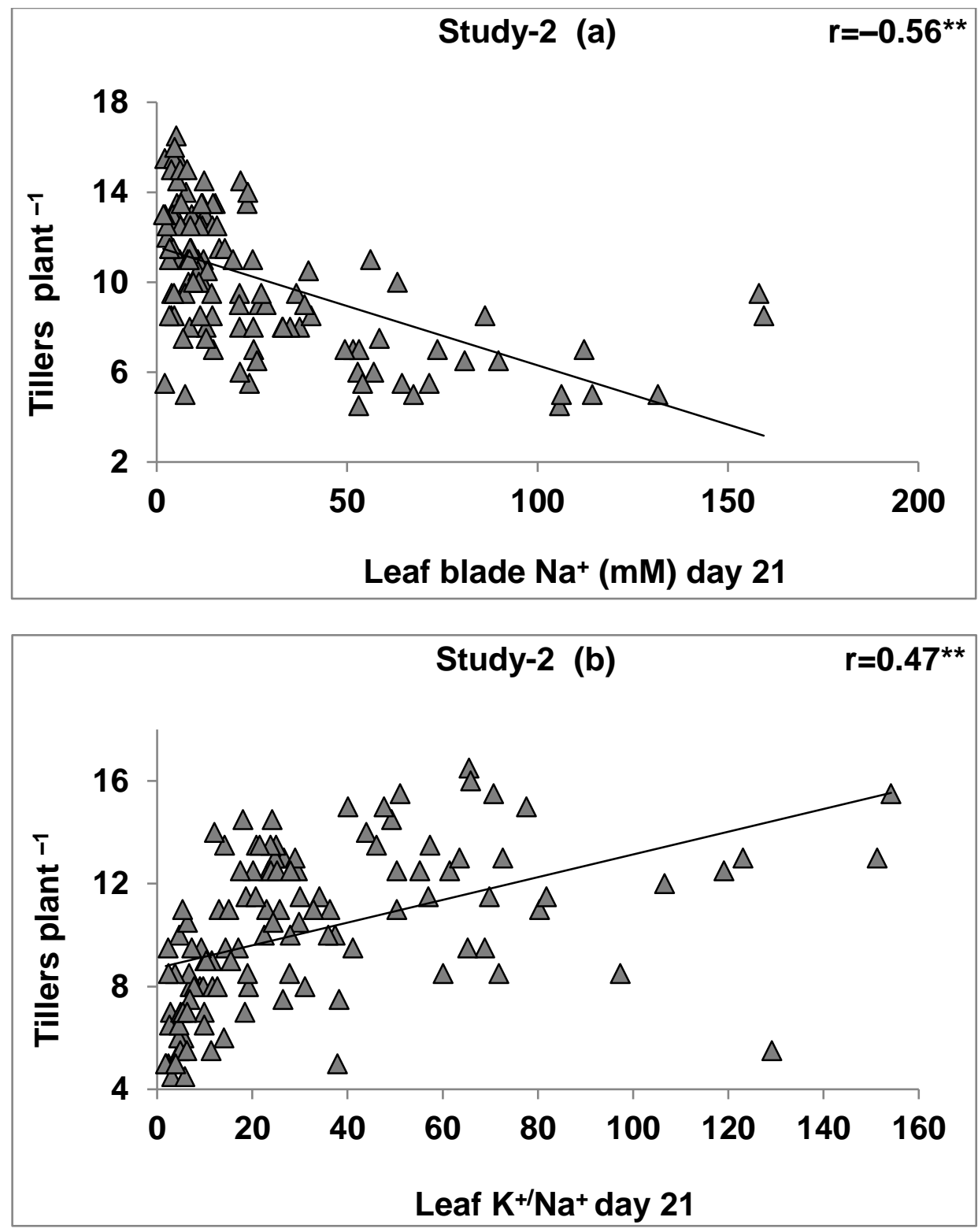

3

Fig.5. Relationship of (a) leaf blade sap $\mathrm{Na}^{+}$with Tillers plant ${ }^{-1}$ and (b) Leaf blade sap $\mathrm{K}^{+} / \mathrm{Na}^{+}$ with tillers plant ${ }^{-1}$ on day 21/42 of salt stress in Study-2. $r=$ Pearson's correlation coefficient (2-tailed) 

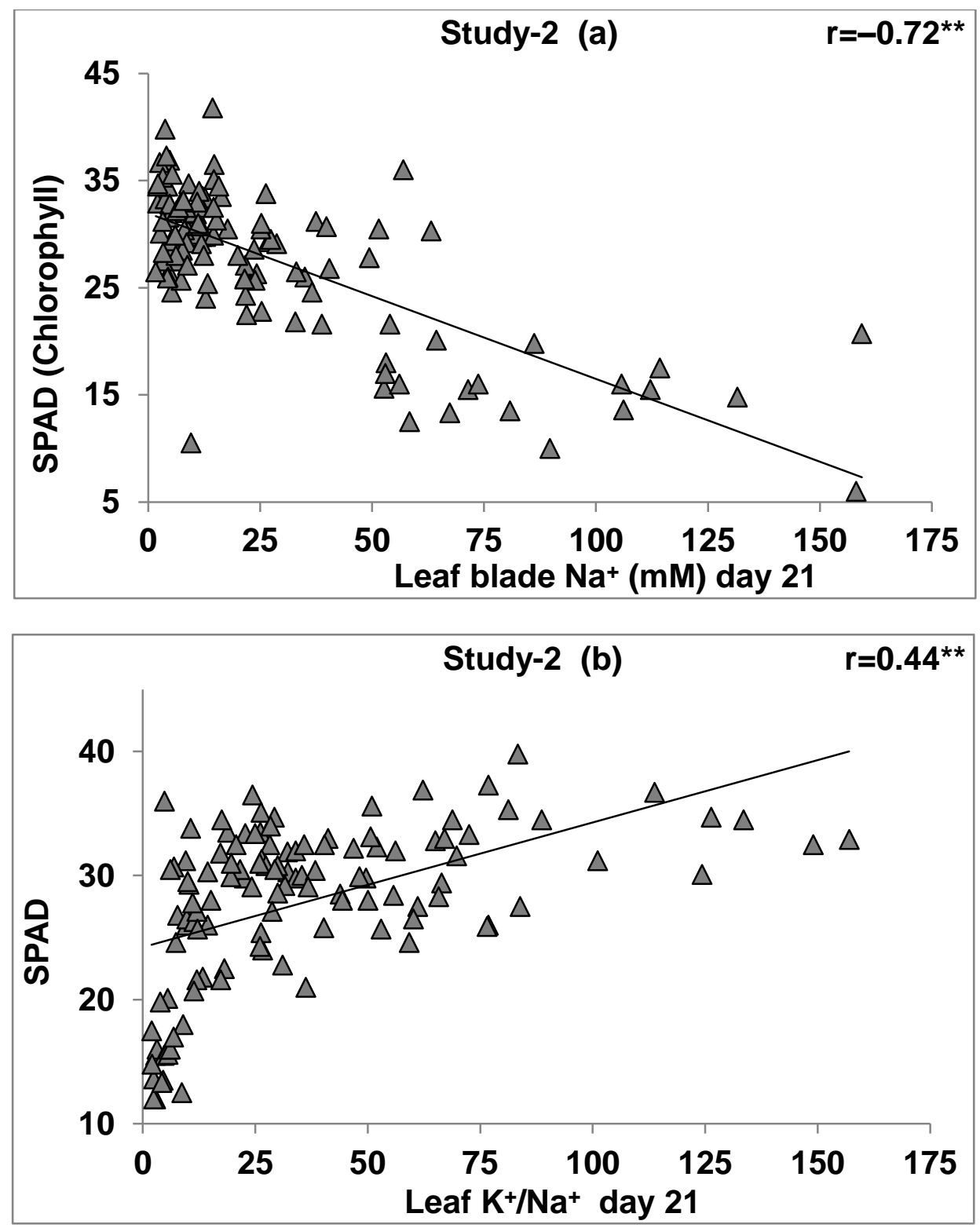

3

4 Fig. 6. Relationship of (a) SPAD (Chlorophyll concentration) with leaf blade sap $\mathrm{Na}^{+}$and (b) SPAD with leaf blade sap $\mathrm{K}^{+} / \mathrm{Na}^{+}$on day $21 / 42$ of slat stress in Study-2. $\mathrm{r}=$ Pearson's correlation coefficient (2-tailed) 

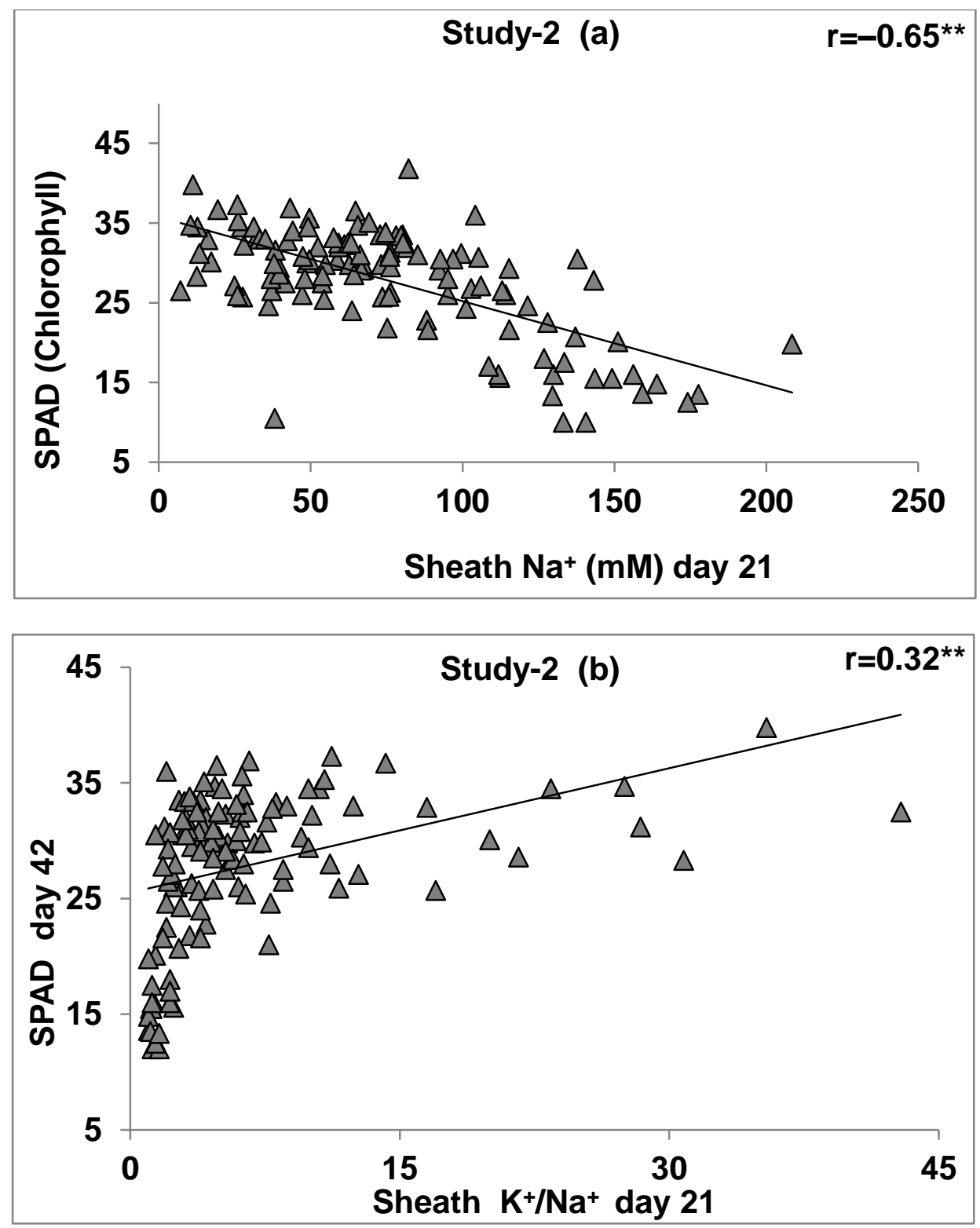

Fig.7. Relationship of (a) SPAD (Chlorophyll concentration) with sheath sap $\mathrm{Na}^{+}$concentration and (b) SPAD with sheath sap $\mathrm{K}^{+} / \mathrm{Na}^{+}$on day 21/42 of salt stress in Study-2. $\mathrm{r}=$ Pearson's correlation coefficient (2-tailed) 
Table 1. Physiological and growth attributes of CO39, Moroberekan and population of 32 RILs grown in control (non-saline) conditions and in $100 \mathrm{mM} \mathrm{NaCl}$ for 42 days (Study-1). Growth was measured on day 42 for both control and saline treatments. For the saline treatment only, ions were measured on day 21 in the youngest fully expanded leaf, and injury scores measured on day 21 and day 42 on a scale of 1-4. Each value is mean of three replicates, except RILs where it is average of 102 plants

\begin{tabular}{|c|c|c|c|c|c|c|c|c|}
\hline \multirow[t]{2}{*}{ Traits } & \multicolumn{2}{|c|}{ CO39 } & \multicolumn{2}{|c|}{ Moroberekan } & \multicolumn{2}{|l|}{ RILs } & \multicolumn{2}{|l|}{ RILs } \\
\hline & Control & Saline & Control & Saline & Control & Range & Saline & Range \\
\hline SFW (g) & 42.1 & 17.5 & 89.8 & 19.5 & 70.6 & $22.8-185.5$ & 21.1 & $8.7-32.5$ \\
\hline SFW \% of control & - & 41.8 & - & 22.6 & - & - & 35.9 & $10.6-110.3$ \\
\hline SDW (g) & 6.8 & 4.3 & 15.2 & 4.6 & 12.6 & $3.79-35.1$ & 5.1 & $2.0-9.0$ \\
\hline SDW \% of control & - & 63.5 & - & 30.2 & - & - & 46.1 & $19.7-93.7$ \\
\hline Tillers plant ${ }^{-1}$ & 11.7 & 9.0 & 12.0 & 4.67 & 11.7 & $3.0-28.0$ & 9.4 & $3.0-18.0$ \\
\hline Shoot water ( $\mathrm{g} \mathrm{g}^{-1} \mathrm{dw}$.) & 5.2 & 3.1 & 4.9 & 3.2 & 4.8 & $3.0-6.8$ & 3.2 & $2.1-4.1$ \\
\hline Leaf $\mathrm{Na}^{+}(\mathrm{mM})$ on day 21 & 1.4 & 14.6 & 1.1 & 63.9 & 1.2 & $0.9-3.0$ & 30.5 & $2.7-136.2$ \\
\hline Leaf $\mathrm{K}^{+}(\mathrm{mM})$ on day 21 & 363 & 336 & 263 & 245 & 277 & $173-397$ & 283 & $166-369$ \\
\hline $\mathrm{K}^{+} / \mathrm{Na}^{+}$ratio on day 21 & 264.5 & 32.9 & 239.7 & 3.8 & 231.8 & $84.5-312.8$ & 27.3 & $2.0-113.1$ \\
\hline $\begin{array}{l}\text { Score-1 on day } 21 \\
\text { (Top leaves) }\end{array}$ & - & 1.3 & - & 1.7 & - & - & 1.8 & $1.0-3.7$ \\
\hline $\begin{array}{l}\text { Score- } 2 \text { on day } 42 \\
\text { (Top leaves) }\end{array}$ & - & 2.0 & - & 2.7 & - & - & 2.5 & $1.0-4.0$ \\
\hline
\end{tabular}


Table 2. Correlation matrix (Pearson's 2-tailed) for various traits of 32 RILs grown in saline (100 mM NaCl) conditions (Study-1).

$\mathrm{Na}, \mathrm{K}$ and $\mathrm{K} / \mathrm{Na}=$ Leaf $\mathrm{Na}, \mathrm{K}$ and ratio on day $21, \mathrm{SFW}=$ Shoot fresh weight $(\mathrm{g}), \mathrm{SDW}=$ Shoot dry weight $(\mathrm{g})$, Tiller $=$ Tillers Plant ${ }^{-1}, S W g g^{-1} d w=S h o o t$ water on dry weight basis, Score-1 \& $2=$ Leaf injury on day 21 and 42 on top leaves

\begin{tabular}{|c|c|c|c|c|c|c|c|c|c|c|c|}
\hline Traits & $\mathrm{Na}^{+}$ & $\mathrm{K}^{+}$ & $\mathrm{K}^{+} / \mathrm{Na}^{+}$ & SFW & SDW & SDW\%C & Tiller & $\mathrm{SW} \mathrm{g} \mathrm{g}^{-1}$ & SFW\%C & Score -1 & Score -2 \\
\hline $\mathrm{K}^{+}$ & $-0.415^{* *}$ & 1.0 & & & & & & & & & \\
\hline $\mathrm{K}^{+} / \mathrm{Na}^{+}$ & $-0.652 * *$ & $0.519 * *$ & 1.0 & & & & & & & & \\
\hline SFW & $-0.093^{\mathrm{NS}}$ & $0.346^{* *}$ & $0.154^{\mathrm{NS}}$ & 1.0 & & & & & & & \\
\hline SDW & $0.018^{\mathrm{NS}}$ & $0.372 * *$ & $0.146^{\mathrm{NS}}$ & $0.938 * *$ & 1.0 & & & & & & \\
\hline SDW\%C & $-0.145^{\mathrm{NS}}$ & $0.096^{\mathrm{NS}}$ & $0.019^{\mathrm{NS}}$ & $0.362 * *$ & $0.246^{*}$ & 1.0 & & & & & \\
\hline Tillers & $-0.224 *$ & $0.520 * *$ & $0.489 * *$ & $0.610 * *$ & $0.667 * *$ & $0.288 * *$ & 1.0 & & & & \\
\hline $\mathrm{SW} \mathrm{g} \mathrm{g}^{-1} \mathrm{DW}$ & $-0.274 * *$ & $-0.150^{\mathrm{NS}}$ & $-0.021^{\mathrm{NS}}$ & $-0.065^{\mathrm{NS}}$ & $-0.398 * *$ & $0.199 *$ & $-0.333^{* *}$ & 1.0 & & & \\
\hline SFW\%C & $-0.170^{\mathrm{NS}}$ & $0.079^{\mathrm{NS}}$ & $0.032^{\mathrm{NS}}$ & $0.395 * *$ & $0.250 *$ & $0.983 * *$ & $0.266^{* *}$ & $0.273 * *$ & 1.0 & & \\
\hline Score -1 & $0.130^{\mathrm{NS}}$ & $0.012^{\mathrm{NS}}$ & $0.071^{\mathrm{NS}}$ & $0.095^{\mathrm{NS}}$ & $0.184^{\mathrm{NS}}$ & $-0.013^{\mathrm{NS}}$ & $-0.252 *$ & $-0.295 * *$ & $-0.091^{\mathrm{NS}}$ & 1.0 & \\
\hline Score -2 & $0.689 * *$ & $-0.532 * *$ & $-0.638 * *$ & $-0.307 * *$ & $-0.191^{\mathrm{NS}}$ & $-0.231 *$ & $-0.332 * *$ & $-0.271 * *$ & $-0.242 *$ & $0.162^{\mathrm{NS}}$ & 1.0 \\
\hline
\end{tabular}

$*, * *=$ Correlation was significant at $\leq 0.05$ and 0.01 levels, respectively, NS $=$ non-significant 
Table 3. Physiological and growth attributes of CO39, Moroberekan and population of 120 RILs grown in $100 \mathrm{mM}$ NaCl for 42 days (Study-2). Ions are given on day 21 in the youngest fully expanded leaf, and injury scores on day 21 and day 42 on a scale of 1-4. Each value is mean of two replicates, except RILs where it is average of 240 plants.

\begin{tabular}{|c|c|c|c|c|}
\hline Traits & $\mathrm{CO} 39$ & Moroberekan & RILs & RILs range \\
\hline \multicolumn{5}{|c|}{ Growth, ions and injury on day 21/42 of salt stress } \\
\hline Shoot fresh weight $(\mathrm{g})$ on day 42 & $29.5 \pm 1.16$ & $11.04 \pm 1.78$ & $24.07 \pm 0.61$ & $9.6-40.9$ \\
\hline Shoot dry weight (g) on day 42 & $7.78 \pm 0.08$ & $3.81 \pm 0.12$ & $6.47 \pm 0.15$ & $3.3-10.8$ \\
\hline Tillers plant ${ }^{-1}$ on day 42 & $15.0 \pm 1.15$ & $5.0 \pm 0.58$ & $10.14 \pm 0.28$ & $4.5-16.5$ \\
\hline SPAD on day 42 & $33.13 \pm 0.32$ & $13.33 \pm 0.88$ & $27.80 \pm 0.63$ & $10-41.8$ \\
\hline Shoot water ( $\left.\mathrm{g} \mathrm{g}^{-1} \mathrm{dw}.\right)$ & $2.80 \pm 0.18$ & $1.89 \pm 0.42$ & $2.71 \pm 0.04$ & $1.42-3.61$ \\
\hline $\mathrm{Na}^{+}$in leaf blade & $7.9 \pm 2.1$ & $67.4 \pm 15.8$ & $26.2 \pm 3.0$ & $2.1-159.4$ \\
\hline $\mathrm{Na}^{+}$in sheath & $57.6 \pm 10.5$ & $129.7 \pm 15.2$ & $75.3 \pm 3.9$ & $10.6-208.5$ \\
\hline $\mathrm{K}^{+}$in leaf blade & $317 \pm 19$ & $264 \pm 30$ & $298 \pm 3$ & $194-401$ \\
\hline $\mathrm{K}^{+}$in sheath & $303 \pm 35$ & $208 \pm 15$ & $258 \pm 4$ & $154-355$ \\
\hline $\mathrm{K}^{+} / \mathrm{Na}^{+}$in leaf blade & $47.5 \pm 14.6$ & $4.2 \pm 0.6$ & $36.2 \pm 3.0$ & $1.8-154.2$ \\
\hline $\mathrm{K}^{+} / \mathrm{Na}^{+}$in sheath & $5.7 \pm 1.2$ & $1.65 \pm 0.2$ & $6.6 \pm 0.7$ & $1.0-26.7$ \\
\hline Injury Score-1 on day 21 & $1.4 \pm 0.3$ & $3.7 \pm 0.5$ & $1.7 \pm 0.1$ & $1.0-3.8$ \\
\hline Injury Score- 2 on day 42 & $2.4 \pm 0.3$ & $3.9 \pm 0.0$ & $2.3 \pm 0.1$ & $1.0-4.0$ \\
\hline
\end{tabular}

Each mean value is average of 2 repeats \pm SEM, except RILs where it is average of 102/240 plants 
Table 4. Correlation matrix for ion accumulation in leaf blade and sheath for 120 RILs on day 7 and 21, injury scores on day 21 (Score-1) and day 42 (Score-2) and growth traits on day 42 under salts stress (100 mM NaCl) (Study-2)

\begin{tabular}{|c|c|c|c|c|c|c|c|c|c|c|c|c|}
\hline & LNa7 & LK7 & LK/Na7 & LNa21 & LK21 & LK/Na21 & Tillers & SPAD & SFW & SDW & WC g/g & Score-1 \\
\hline LNa7 & 1.0 & & & & & & & & & & & \\
\hline LK 7 & $-0.25 * *$ & 1.0 & & & & & & & & & & \\
\hline LK/Na7 & $-0.67 * *$ & $0.40 * *$ & 1.0 & & & & & & & & & \\
\hline LNa21 & $0.47 * *$ & $-0.30 * *$ & $-0.43 * *$ & 1.0 & & & & & & & & \\
\hline LK21 & $-0.01^{\mathrm{NS}}$ & $0.50 * *$ & $0.06^{\mathrm{NS}}$ & $-0.19 *$ & 1.0 & & & & & & & \\
\hline LK/Na21 & $-0.47 * *$ & $0.27 * *$ & $0.73 * *$ & $-0.57 * *$ & $-0.09^{\mathrm{NS}}$ & 1.0 & & & & & & \\
\hline Tillers & $-0.24 * *$ & $0.35^{* *}$ & $0.25^{*}$ & $-0.56 * *$ & $0.07^{\mathrm{NS}}$ & $0.47 * *$ & 1.0 & & & & & \\
\hline SPAD & $-0.32 * *$ & $0.10^{\mathrm{NS}}$ & $0.27 * *$ & $-0.72 * *$ & $0.30 * *$ & $0.44 * *$ & $0.48 * *$ & 1.0 & & & & \\
\hline SFW & $-0.27 * *$ & $0.28 * *$ & $0.19^{\mathrm{NS}}$ & $-0.63 * *$ & $-0.13^{\mathrm{NS}}$ & $0.40 * *$ & $0.62 * *$ & $0.67 * *$ & 1.0 & & & \\
\hline SDW & $-0.21^{*}$ & $0.33 * *$ & $0.22 *$ & $-0.48 * *$ & $-0.08^{\mathrm{NS}}$ & $0.44 * *$ & $0.62 * *$ & $0.53 * *$ & $0.91 * *$ & 1.0 & & \\
\hline SW g/g & $-0.30 * *$ & $0.02^{\mathrm{NS}}$ & $0.07^{\mathrm{NS}}$ & $-0.60 * *$ & $-0.14^{\mathrm{NS}}$ & $0.12^{\mathrm{NS}}$ & $0.23 * *$ & $0.57 * *$ & $0.52 * *$ & $0.17^{\mathrm{NS}}$ & 1.0 & \\
\hline Score-1 & $0.08^{\mathrm{NS}}$ & $0.06^{\mathrm{NS}}$ & $0.06^{\mathrm{NS}}$ & $0.35 * *$ & $0.12^{\mathrm{NS}}$ & $-0.14^{\mathrm{NS}}$ & $-0.42 * *$ & $-0.54 * *$ & $-0.38 * *$ & $-0.28 * *$ & $-0.38 * *$ & 1.0 \\
\hline Score-2 & $0.32 * *$ & $-0.17^{\mathrm{NS}}$ & $-0.27 * *$ & $0.71 * *$ & $0.27 *$ & $-0.46^{* *}$ & $-0.55 * *$ & $-0.87 * *$ & $-0.72 * *$ & $-0.57 * *$ & $-0.54 * *$ & $0.55^{* *}$ \\
\hline
\end{tabular}

$*, * *=$ Pearson correlation ( 2 tailed) significant $\leq 0.05$ and 0.01 levels, respectively

NS = Non significant

LK7 = Leaf $\mathrm{K}^{+}$concentration on day 7

$\mathrm{LK} / \mathrm{Na} 7=$ Leaf $\mathrm{K}^{+} / \mathrm{Na}^{+}$ratio on day 7

$\mathrm{L} \mathrm{Na} 21=$ Leaf $\mathrm{Na}^{+}$concentration on day 21

LK21 = Leaf $\mathrm{K}^{+}$concentration on day 21

$\mathrm{LK} / \mathrm{Na} 21=$ Leaf $\mathrm{K}^{+} / \mathrm{Na}^{+}$ratio on day 21 


\section{Supplementary Table 1}

Mean squares of different traits studied in CO39×Moroborekan RILs ( $\mathrm{n}=34$ ) on day 21 (ions) or day 42 (growth) in saline and non-saline conditions (Study-1).

\begin{tabular}{|c|c|c|c|c|c|c|c|c|}
\hline SOV & D.F & Leaf $\mathrm{Na}^{+}$ & Leaf $\mathrm{K}^{+}$ & $\mathrm{K}^{+} / \mathrm{Na}^{+}$ & SFW & SDW & Tillers Plant ${ }^{-1}$ & $\mathrm{SW} \mathrm{g} \mathrm{g}^{-1} \mathrm{dw}$ \\
\hline Salinity & 1 & $43610.2 * *$ & $2993.8^{* *}$ & $2118399.1 * *$ & $124715.3^{* *}$ & $2835.1 * *$ & $241.5^{* *}$ & $128.8 * *$ \\
\hline RILs & 33 & $1089.4 * *$ & $6307.4 * *$ & $5292.8 * *$ & $1408.8 * *$ & $61.7 * *$ & $71.9 * *$ & $0.92 * *$ \\
\hline Salinity $\times$ RILs & 33 & $1079.5^{* *}$ & $1654.9 * *$ & $1523.1 * *$ & $1203.9 * *$ & $43.5^{* *}$ & $21.8^{* *}$ & $0.22^{\mathrm{NS}}$ \\
\hline
\end{tabular}

${ }^{*},{ }^{* *}=$ Means were significant at $\leq 0.05$ and 0.01 levels, respectively

NS = Means difference was non-significant 


\section{Supplementary Table-2a}

Correlation matrix for ion accumulation in the leaf sheath on day 7/21, growth traits on day 42 and injury scores on day 21 (Score-1) or day 42 (Score2) under salt stress (100 mM NaCl) (Study-2)

\begin{tabular}{|c|c|c|c|c|c|c|}
\hline & SNa7 & SK7 & SK/Na7 & SNa21 & SK21 & SK/Na21 \\
\hline SNa7 & 1.0 & & & & & \\
\hline SK7 & $-0.31 * *$ & 1.0 & & & & \\
\hline SK/Na7 & $-0.71 * *$ & $0.38 * *$ & 1.0 & & & \\
\hline SNa21 & $0.64 * *$ & $-0.28 * *$ & $-0.55 * *$ & 1.0 & & \\
\hline SK21 & $-0.50 * *$ & $0.34 * *$ & $0.36 * *$ & $-0.75^{* *}$ & 1.0 & \\
\hline SK/Na21 & $-0.53 * *$ & $0.30 * *$ & $0.77 * *$ & $-0.68 * *$ & $0.52 * *$ & 1.0 \\
\hline Tillers & $-0.29 * *$ & $0.28 * *$ & $0.28 * *$ & $-0.56 * *$ & $0.64 * *$ & $0.35^{* *} *$ \\
\hline SPAD & $-0.31 * *$ & $0.07^{\mathrm{NS}}$ & $0.29 * *$ & $-0.65 * *$ & $0.49 * *$ & $0.32 * *$ \\
\hline SFW & $-0.33 * *$ & $0.19^{\mathrm{NS}}$ & $0.17^{\mathrm{NS}}$ & $-0.59 * *$ & $0.60 * *$ & $0.38 * *$ \\
\hline SDW & $-0.32^{* *}$ & $0.25 *$ & $0.27 * *$ & $-0.53 * *$ & $0.54 * *$ & $0.47 * *$ \\
\hline SW g/g & $-0.19^{\mathrm{NS}}$ & $-0.02^{\mathrm{NS}}$ & $-0.08^{\mathrm{NS}}$ & $-0.39 * *$ & $0.37 * *$ & $0.01^{\mathrm{NS}}$ \\
\hline Score-1 & $0.14^{\mathrm{NS}}$ & $0.20 *$ & $-0.04^{\mathrm{NS}}$ & $0.26 * *$ & $-0.27 * *$ & $0.01^{\mathrm{NS}}$ \\
\hline Score-2 & $0.31 * *$ & $-0.13^{\mathrm{NS}}$ & $-0.25 * *$ & $0.66^{* *}$ & $-0.51 * *$ & $-0.28 * *$ \\
\hline
\end{tabular}

$\mathrm{SNa} 7=$ Sheath $\mathrm{Na}^{+}$concentration on day 7

SK7 = Sheath $\mathrm{K}^{+}$concentration on day 7

$\mathrm{SK} / \mathrm{Na} 7=$ Sheath $\mathrm{K}^{+} / \mathrm{Na}^{+}$ratio on day 7

$\mathrm{SNa} 21=$ Sheath $\mathrm{Na}^{+}$concentration on day 21

SK21 = Sheath $\mathrm{K}^{+}$concentration on day 21

$\mathrm{SK} / \mathrm{Na} 21=$ Sheath $\mathrm{K}^{+} / \mathrm{Na}^{+}$ratio on day 21 
Supplementary. Table-2b

Correlation matrix for ion accumulation in the leaf blade versus the leaf sheath on day 7/21, under salt stress (100 mM NaCl) (Study-2)

\begin{tabular}{|c|c|c|c|c|c|c|c|c|c|c|c|}
\hline & LNa7 & LK7 & LK/Na7 & LNa21 & LK21 & LK/Na21 & SNa7 & SK7 & SK/Na7 & SNa21 & SK21 \\
\hline LK 7 & $-0.25^{* *}$ & 1.0 & & & & & & & & & \\
\hline LK/Na7 & $-0.67 * *$ & $0.40 * *$ & 1.0 & & & & & & & & \\
\hline LNa21 & $0.47 * *$ & $-0.30 * *$ & $-0.43 * *$ & 1.0 & & & & & & & \\
\hline LK21 & $-0.01^{\mathrm{NS}}$ & $0.50^{* *}$ & $0.06^{\mathrm{NS}}$ & $0.19^{*}$ & 1.0 & & & & & & \\
\hline LK/Na21 & $-0.47 * *$ & $0.27 * *$ & $0.73^{* *}$ & $-0.57 * *$ & $-0.09^{\mathrm{NS}}$ & 1.0 & & & & & \\
\hline SNa7 & $0.80^{* *}$ & $-0.19 * *$ & $-0.76^{* *}$ & $0.43 * *$ & $0.09^{\mathrm{NS}}$ & $-0.57 * *$ & 1.0 & & & & \\
\hline SK7 & $-0.36^{* *}$ & $0.65^{* *}$ & $0.55^{* *}$ & $-0.30^{* *}$ & $0.29 * *$ & $0.40^{* *}$ & $-0.31^{* *}$ & 1.0 & & & \\
\hline SK/Na7 & $-0.46^{* *}$ & $0.24 *$ & $0.75^{* *}$ & $-0.34 * *$ & $-0.10^{\mathrm{NS}}$ & $0.67 * *$ & $-0.71 * *$ & $0.38 * *$ & 1.0 & & \\
\hline SNa21 & $0.57 * *$ & $-0.18^{\mathrm{NS}}$ & $-0.59 * *$ & $0.79 * *$ & $0.24 * *$ & $-0.77 * *$ & $0.64 * *$ & $-0.28 * *$ & $-0.55^{* *}$ & 1.0 & \\
\hline SK21 & $-0.47^{* *}$ & $0.31 * *$ & $0.47 * *$ & $-0.71 * *$ & $0.02^{\mathrm{NS}}$ & $0.58 * *$ & $-0.50^{* *}$ & $0.34 * *$ & $0.36^{* *}$ & $-0.75^{* *}$ & 1.0 \\
\hline SK/Na21 & $-0.38^{* *}$ & $0.15^{\mathrm{NS}}$ & $0.60 * *$ & $-0.40 * *$ & $-0.16^{\mathrm{NS}}$ & $0.78^{* *}$ & $-0.53^{* *}$ & $0.30 * *$ & $0.77 * *$ & $-0.68^{* *}$ & $0.52 * *$ \\
\hline
\end{tabular}

LK7 $=$ Leaf $\mathrm{K}^{+}$concentration on day 7

$\mathrm{LK} / \mathrm{Na} 7=$ Leaf $\mathrm{K}^{+} / \mathrm{Na}^{+}$ratio on day 7

$\mathrm{L} \mathrm{Na} 21=$ Leaf $\mathrm{Na}^{+}$concentration on day 21

LK21 = Leaf $\mathrm{K}^{+}$concentration on day 21

$\mathrm{LK} / \mathrm{Na} 21=$ Leaf $\mathrm{K}^{+} / \mathrm{Na}^{+}$ratio on day 21 

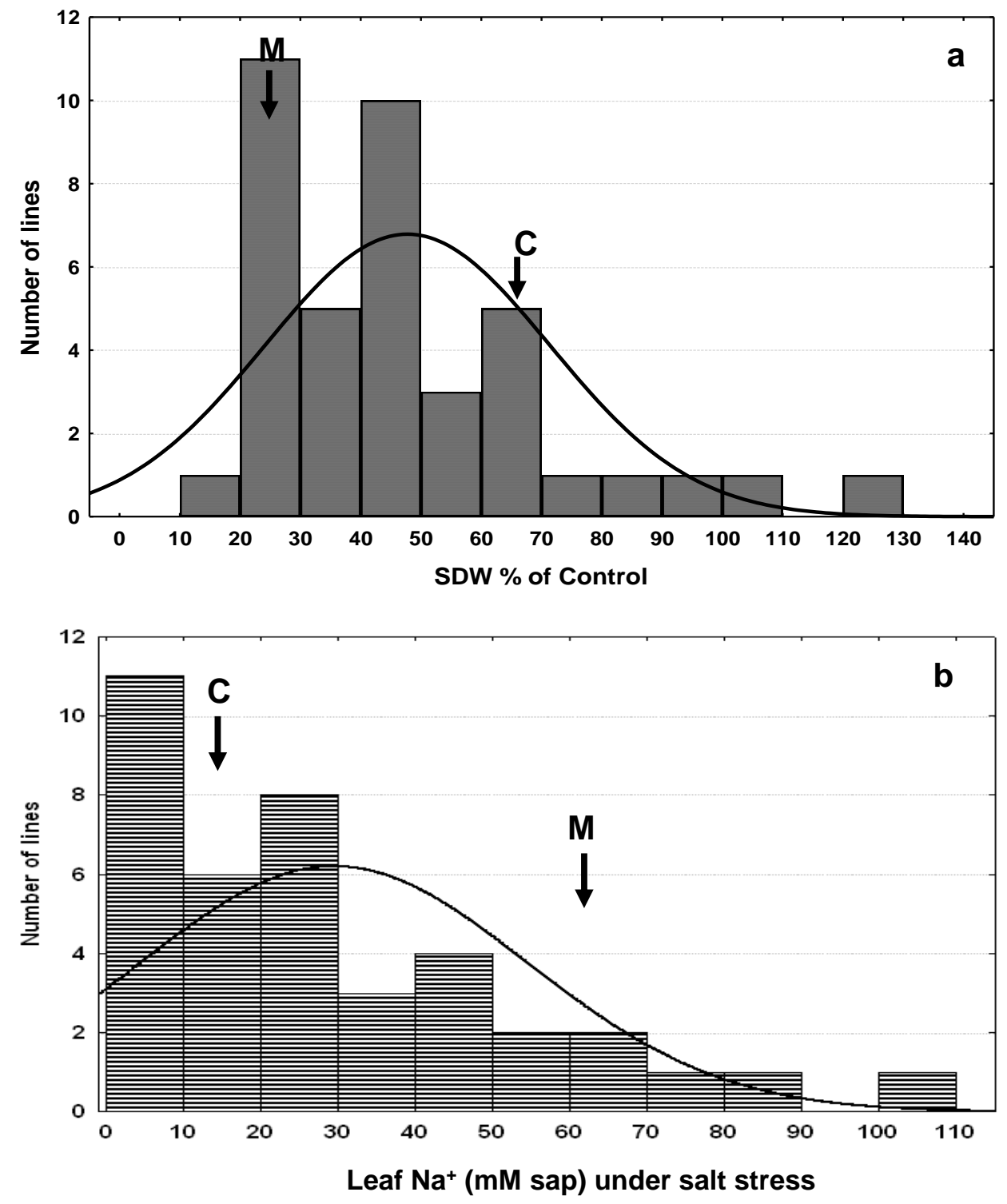

Suppl. Fig. 1. (a) Frequency distribution for shoot dry weight and (b) leaf blade $\mathrm{Na}^{+}$under salt stress in RIL population $(n=32)$ in Study-1. The arrows indicate mean values for CO39 and Moroberekan 

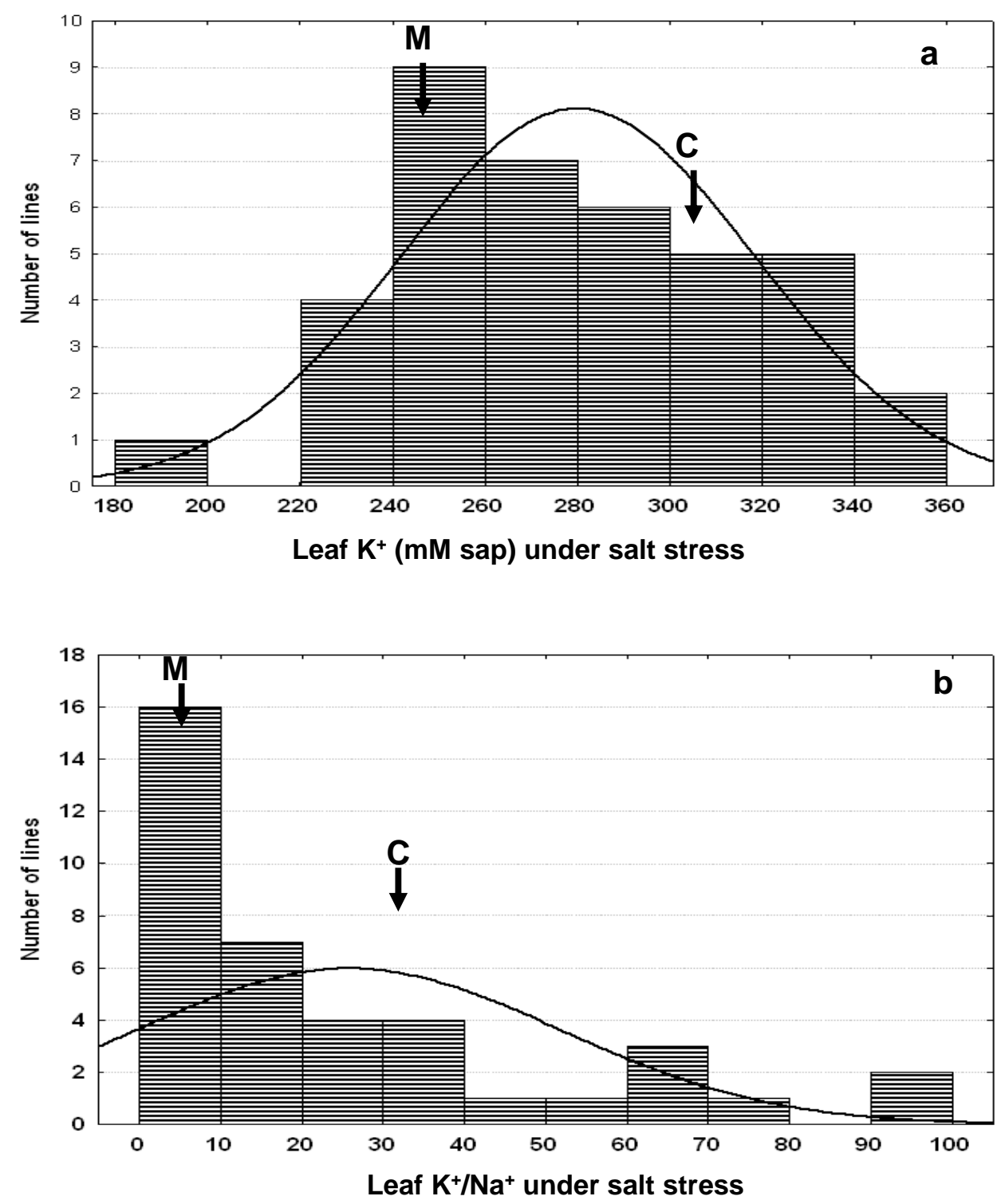

Suppl Fig. 2. (a) Frequency distribution for leaf blade $\mathrm{K}^{+}$and (b) leaf blade $\mathrm{K}^{+} / \mathrm{Na}^{+}$in $\mathrm{RIL}$ population $(\mathrm{n}=32)$ under saline treatment in Study-1. The arrows indicate mean values for CO39 and Moroberekan 


\section{Delete these and also following pair of graphs?}
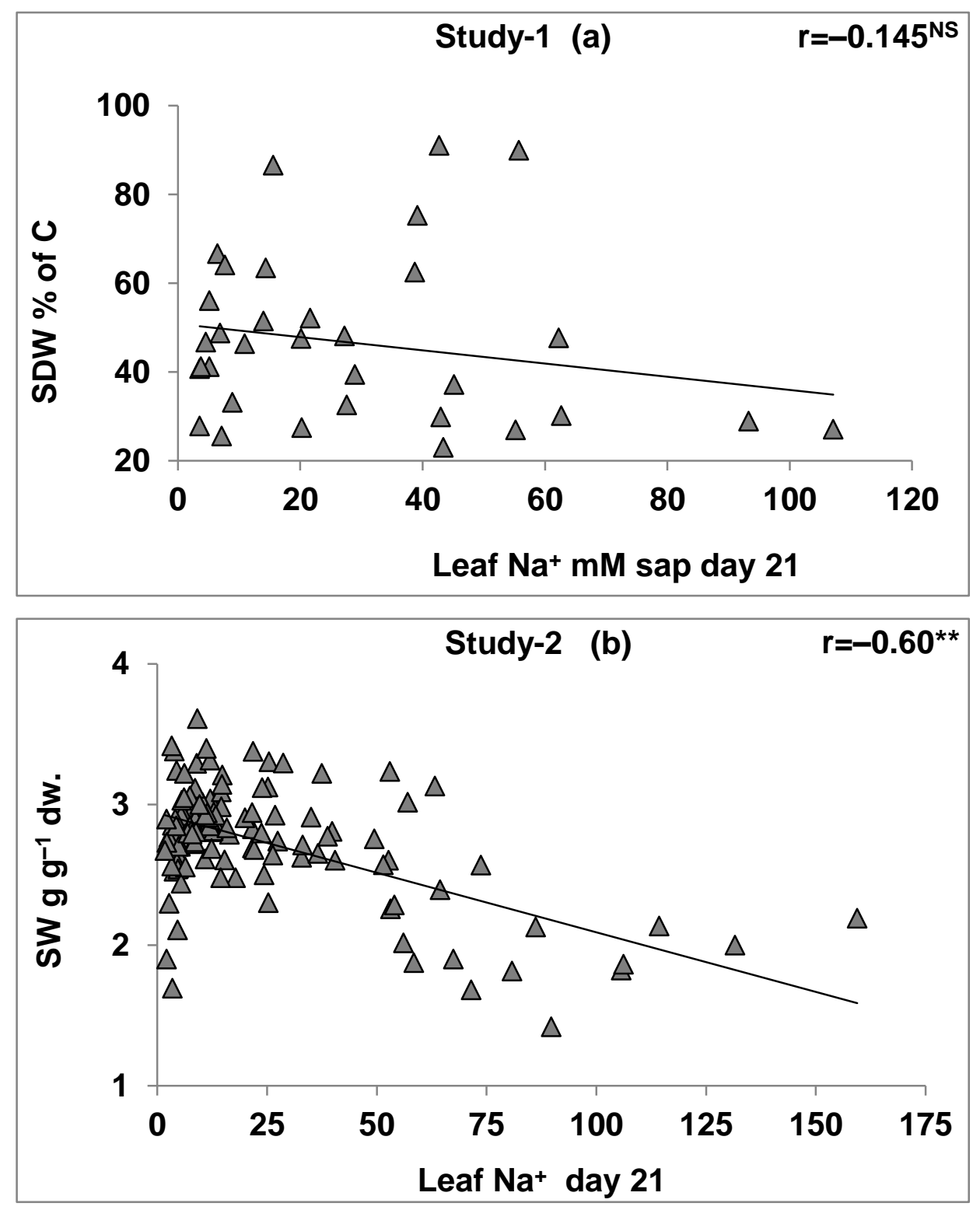

Suppl Fig. 3. Relationships of (a) SDW \% of control with leaf blade $\mathrm{Na}^{+}$in study-1 and (b) Shoot water with leaf blade $\mathrm{Na}^{+}$in Study-2 on day 21/42 of salt stress. $\mathrm{r}=$ Pearson's correlation coefficient (2-tailed) 

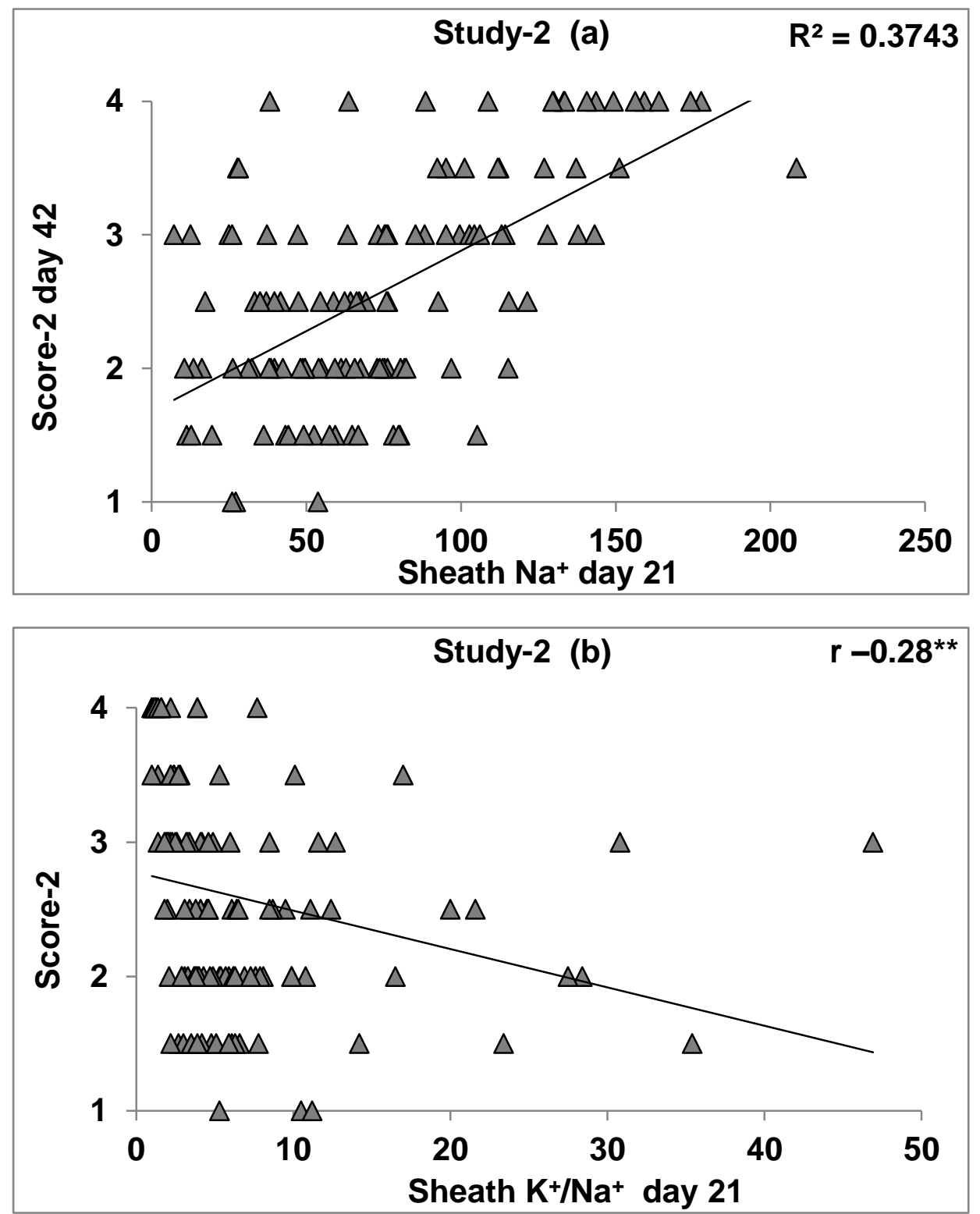

Suppl Fig. 4. Relationship of (a) Leaf injury Score- 2 with $\mathrm{Na}^{+}$concentration in sap of leaf sheath and (b) Score-2 with $\mathrm{K}^{+} / \mathrm{Na}^{+}$in sheath on day $21 / 42$ of salt stress in Study-2. $\mathrm{r}=$ Pearson's correlation coefficient (2-tailed) 

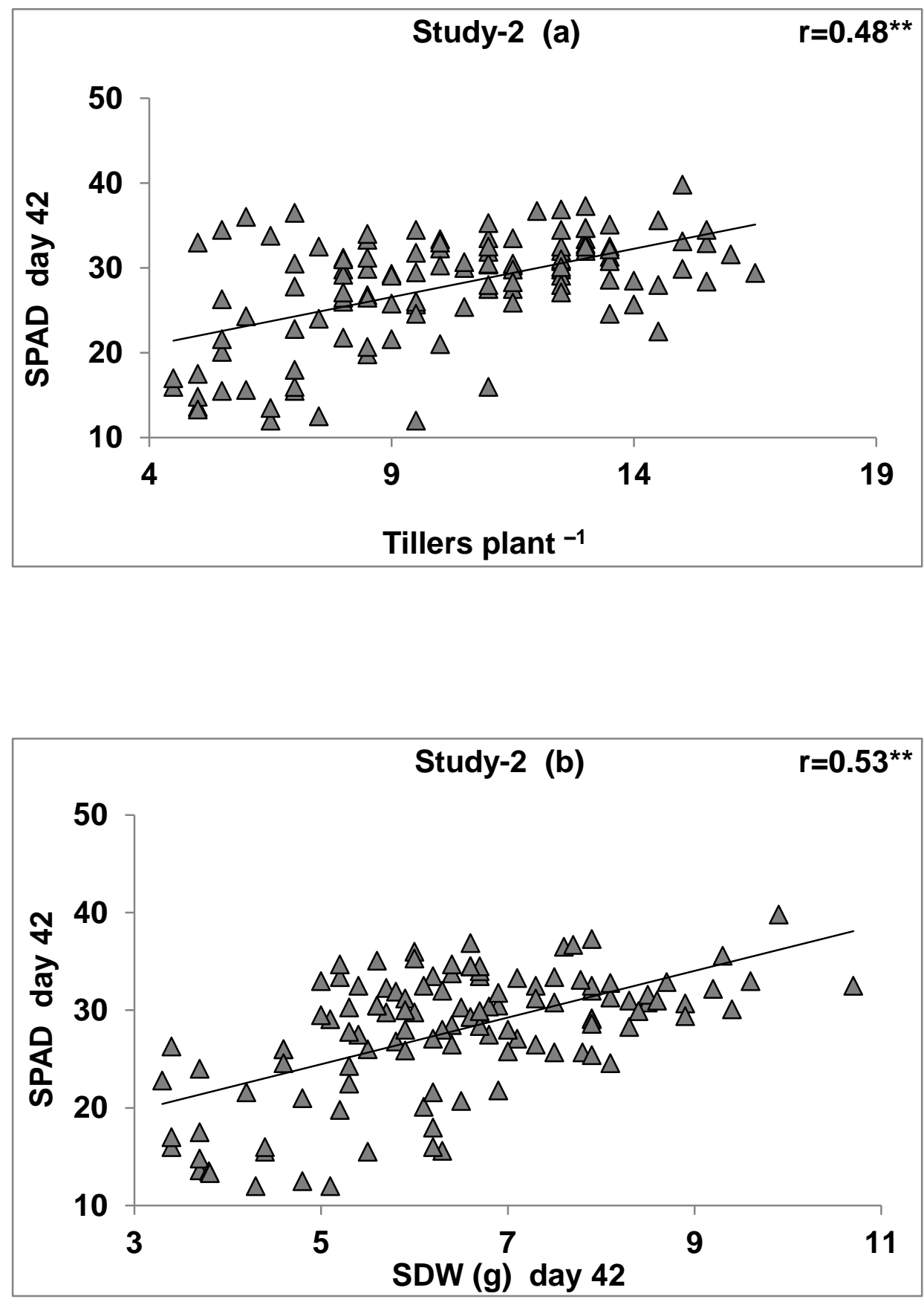

Supplemental Fig.8 ?????. Relationship of (a) SPAD (Chlorophyll) with Tillers plant ${ }^{-1}$ and (b) SPAD with SDW (g) on day 21/42 of slat stress in Study-2. r = Pearson's correlation coefficient (2-tailed) 


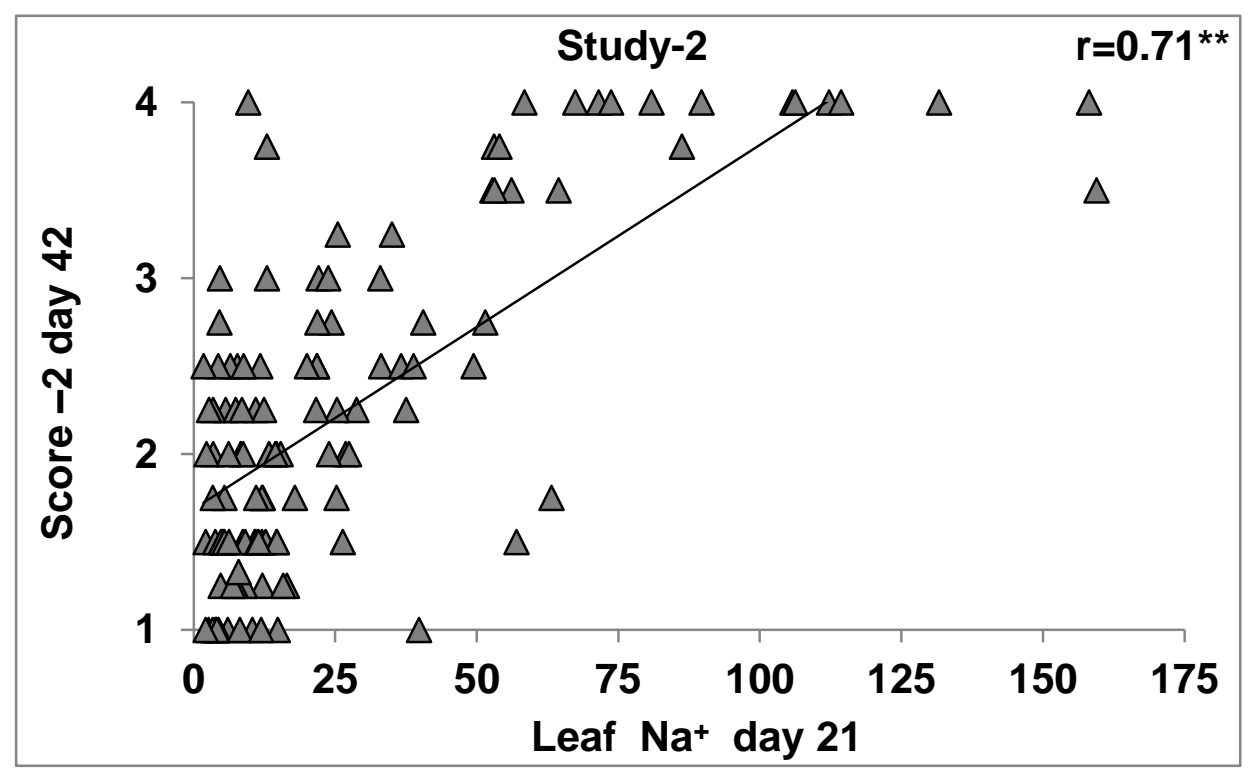

Supplemental Fig.9 ????. Relationship of leaf blade $\mathrm{Na}^{+}$concentration with Score-2 on day 21/42 of salt stress in Study-2. $r=$ Pearson's correlation coefficient (2-tailed) 



Fig.10. Differential salinity leaf damage in (a) parent varieties (CO39 \& Moroberekan) and (b) randomly selected two RILs after 42 days growth under salt stress in Study-2 